\title{
A Breathing Metal-Organic Framework Based on Flexible Inorganic Building Units
}

\section{Supplementary Information}

Erik Svensson Grape, ${ }^{\dagger}$ Hongyi Xu, ${ }^{\dagger}$ Ocean Cheung, ${ }^{\ddagger}$ Marion Calmels, ${ }^{\S}$ Jingjing Zhao, ${ }^{\dagger}$

Catherine Dejoie, ${ }^{\perp}$ Davide M. Proserpio,,$\|, \nabla$ Xiaodong Zou, ${ }^{\dagger}$ A. Ken Inge ${ }^{\star, \dagger}$

†Department of Materials and Environmental Chemistry, Stockholm University, SE 10691 Stockholm, Sweden

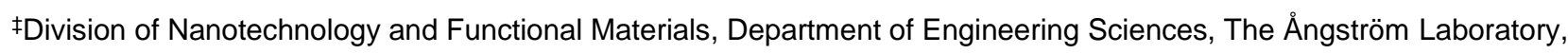
Uppsala University, Box 534, SE-751 21 Uppsala, Sweden

§INSA Lyon - Départment Sciences et Génie Des Matériaux, 69621 Villeurbanne Cedex, France

॥ ESRF - the European Synchrotron Radiation Facility, CS40220, Grenoble 38043, France

¿Dipartimento di Chimica, Università degli Studi di Milano, Milano, 20133, Italy

$\nabla$ Samara Center for Theoretical Materials Science (SCTMS), Samara State Technical University, Samara 443100, Russia 


\section{Table of Contents}

Figure S1. An overview of the synthetic routes used to obtain the five title compounds.

Figure S2. SEM micrograph of $\mathrm{Bi}(\mathrm{BPT}) \cdot(\mathrm{MeOH})_{2}(\mathrm{SU}-100)(\mathbf{1})$.

Figure S3. Reciprocal space projections for $\mathrm{Bi}(\mathrm{BPT}) \cdot(\mathrm{MeOH})_{2}(\mathrm{SU}-100)$

Figure S4. Plot for the refinement of $\mathrm{Bi}(\mathrm{BPT}) \cdot(\mathrm{MeOH})_{2}(\mathrm{SU}-100$, as synthesized).

Figure S5. Plot for the refinement of $\mathrm{Bi}(\mathrm{BPT}) \cdot(\mathrm{MeOH}) 3(\mathrm{MeOH} @ S U-100)$.

Figure S6. Plot for the refinement of Bi(BPT)•(DEF) (DEF@SU-100).

Figure S7. The esg net and tiling.

Figure S8. Solvent-accessible voids in SU-100.

Figure S9. Plot of the calculated void volume vs. the Bi-Bi distance in the IBU of SU-100.

Figure S10. $\mathrm{N}_{2}$ adsorption/desorption isotherm of SU-100 recorded at liquid $\mathrm{N}_{2}$ temperature.

Figure S11. DFT pore size distribution of SU-100.

Figure S12. $\mathrm{CO}_{2}$ adsorption isotherms of SU-100 recorded at 0,10 and $20^{\circ} \mathrm{C}$

Figure S13. Plot of $\ln (\mathrm{P})$ vs. $1 / \mathrm{T}$ for $\mathrm{CO}_{2}$ adsorption on SU-100.

Figure S14. Calculated heat of $\mathrm{CO}_{2}$ adsorption on SU-100.

Figure S15. $\mathrm{N}_{2}$ adsorption/desorption isotherm of SU-100 exposed to water.

Figure S16. $\mathrm{N}_{2}$ adsorption/desorption isotherm of SU-100 exposed to toluene.

Figure S17. Thermodiffraction measurements of SU-100 in air.

Figure S18. Thermodiffraction measurements of SU-100 under reduced pressure

Figure S19. Diffraction patterns of post-thermodiffraction SU-100.

Figure S20. Diffractograms of SU-100 after being exposed to various solvents.

Figure S21. Thermogravimetric analysis of SU-100.

Figure S22. SEM micrograph of $\mathrm{Bi}_{2} \mathrm{O}_{2}$ (HBPT) (2).

Figure S23. Reciprocal space projections of $\mathrm{Bi}_{2} \mathrm{O}_{2}(\mathrm{HBPT})$ (2).

Figure S24. Plot for the refinement of $\mathrm{Bi}_{2} \mathrm{O}_{2}(\mathrm{HBPT})$ (2).

Figure S25. Tiling found for $\mathrm{Bi}_{2} \mathrm{O}_{2}(\mathrm{HBPT})$ (2).

Figure S26. Alternative tiling found for $\mathrm{Bi}_{2} \mathrm{O}_{2}(\mathrm{HBPT})$ (2).

Figure S27. SEM micrograph of $\mathrm{Bi}(\mathrm{OH})\left(\mathrm{H}_{2} \mathrm{BPT}\right)_{2}\left(\mathrm{H}_{2} \mathrm{O}\right)_{2} \cdot \mathrm{H}_{2} \mathrm{O}(\mathbf{3})$.

Figure S28. Image showing hydrogen bonds in $\mathrm{Bi}(\mathrm{OH})\left(\mathrm{H}_{2} \mathrm{BPT}\right)_{2}\left(\mathrm{H}_{2} \mathrm{O}\right)_{2} \cdot \mathrm{H}_{2} \mathrm{O}(\mathbf{3})$.

Figure S29. Measured and simulated powder pattern for $\mathrm{Bi}(\mathrm{OH})\left(\mathrm{H}_{2} \mathrm{BPT}\right)_{2}\left(\mathrm{H}_{2} \mathrm{O}\right)_{2} \cdot \mathrm{H}_{2} \mathrm{O}(\mathbf{3})$.

Figure S30. SEM micrograph of $\mathrm{Bi}_{2}(\mathrm{HBPT})_{3}\left(\mathrm{H}_{2} \mathrm{O}\right)_{3} \cdot \mathrm{H}_{3} \mathrm{BPT}$ (4).

Figure S31. Measured and simulated powder pattern for $\mathrm{Bi}_{2}(\mathrm{HBPT})_{3}\left(\mathrm{H}_{2} \mathrm{O}\right)_{3} \bullet \mathrm{H}_{3} \mathrm{BPT}(4)$. 
Figure S32. SEM micrograph of $\mathrm{Bi}_{6} \mathrm{O}_{4}\left(\mathrm{H}_{2} \text { TPTC }\right)_{5}$ (5).

Figure S33. Reciprocal space projection of $\mathrm{Bi}_{6} \mathrm{O}_{4}\left(\mathrm{H}_{2} \mathrm{TPTC}\right)_{5}$ (5).

Figure S34. Plot for the refinement of $\mathrm{Bi}_{6} \mathrm{O}_{4}\left(\mathrm{H}_{2} \text { TPTC }\right)_{5}(\mathbf{5})$.

Table S1. Crystallographic table for electron diffraction data of as-synthesized SU-100.

Table S2. Crystallographic and refinement details for $\mathrm{Bi}(\mathrm{BPT}) \cdot(\mathrm{MeOH})_{2}(\mathrm{SU}-100$, as-synthesized). S4

Table S3. Crystallographic and refinement details for Bi(BPT)•(MeOH) $3(\mathrm{MeOH} @ S U-100)$.

Table S4. Crystallographic and refinement details for Bi(BPT)•(DEF) (DEF@SU-100).

Table S5. Crystallographic table for electron diffraction data of SU-100-HT.

Table S6. Crystallographic table for electron diffraction data of $\mathrm{Bi}_{2} \mathrm{O}_{2}(\mathrm{HBPT})$ (2)

Table S7. Crystallographic and refinement details for $\mathrm{Bi}_{2} \mathrm{O}_{2}$ (HBPT) (2)

Table S8. Crystallographic details for $\mathrm{Bi}(\mathrm{OH})\left(\mathrm{H}_{2} \mathrm{BPT}\right)_{2}\left(\mathrm{H}_{2} \mathrm{O}\right)_{2} \cdot \mathrm{H}_{2} \mathrm{O}(\mathbf{3})$.

Table S9. Crystallographic details for $\mathrm{Bi}_{2}(\mathrm{HBPT})_{3}\left(\mathrm{H}_{2} \mathrm{O}\right)_{3} \bullet \mathrm{H} 3 \mathrm{BPT}$ (4).

Table S10. Crystallographic table for electron diffraction data of $\mathrm{Bi}_{6} \mathrm{O}_{4}\left(\mathrm{H}_{2} T P T C\right)_{5}(5)$.

Table S11. Crystallographic and refinement details for $\mathrm{Bi}_{6} \mathrm{O}_{4}\left(\mathrm{H}_{2} \mathrm{TPTC}\right)_{5}(5)$.

Table S12. Summary of crystallographic details and CCDC numbers of all presented structures.

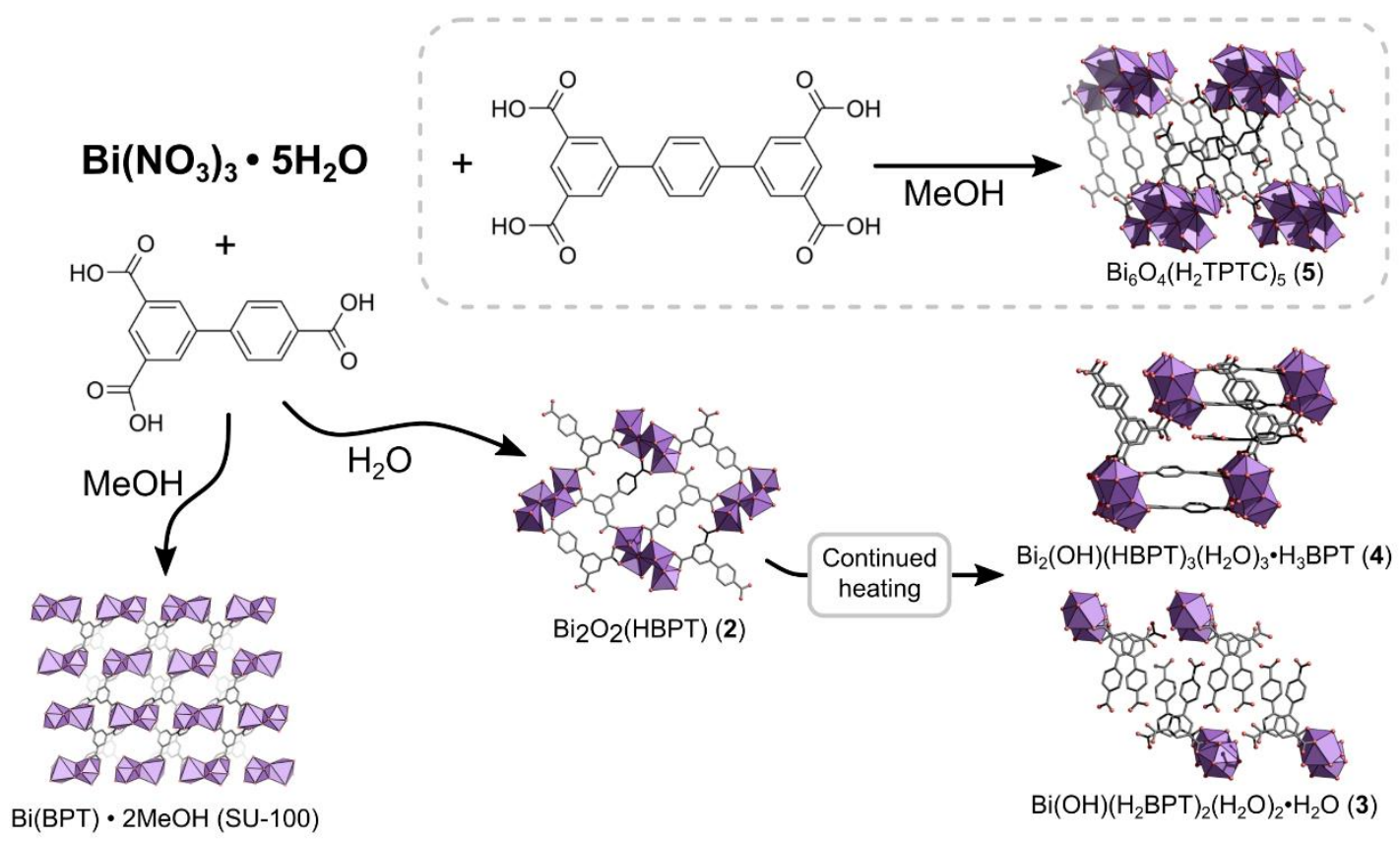

Figure S1. An overview of the syntheses performed in order to obtain the five coordination polymers. Four different phases are obtained with the $\mathrm{H}_{3}$ BPT linker, using either methanol (1) or water as a solvent (2-4). When using $\mathrm{H}_{4}$ TPTC, a single phase is obtained in methanol (5), 


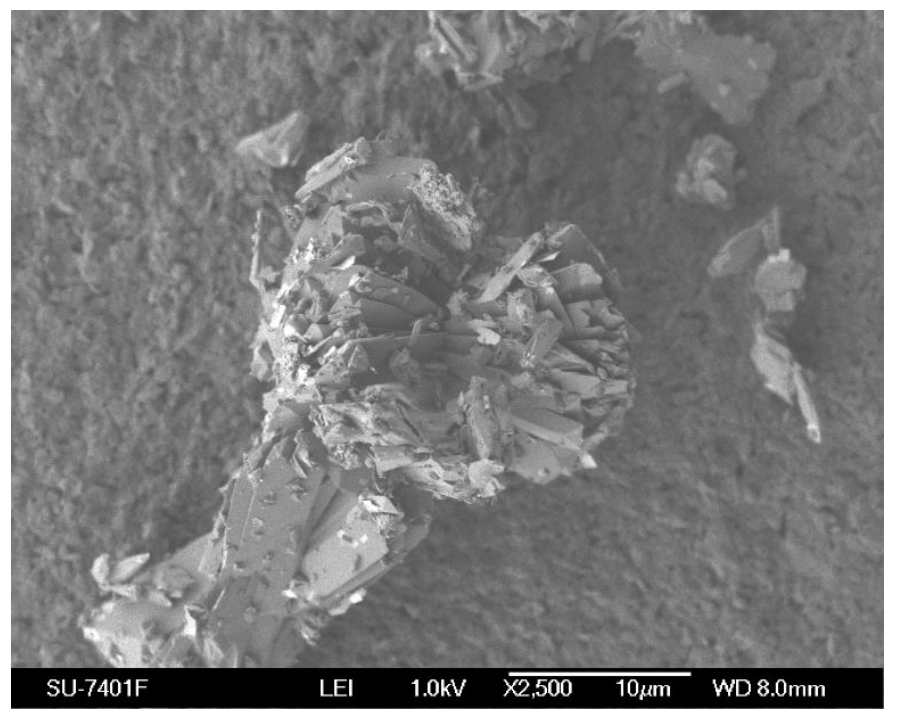

Figure S2. SEM micrograph of $\mathrm{Bi}(\mathrm{BPT}) \cdot(\mathrm{MeOH})_{2}(\mathrm{SU}-100)$, showing an aggregate of plate-like crystals.

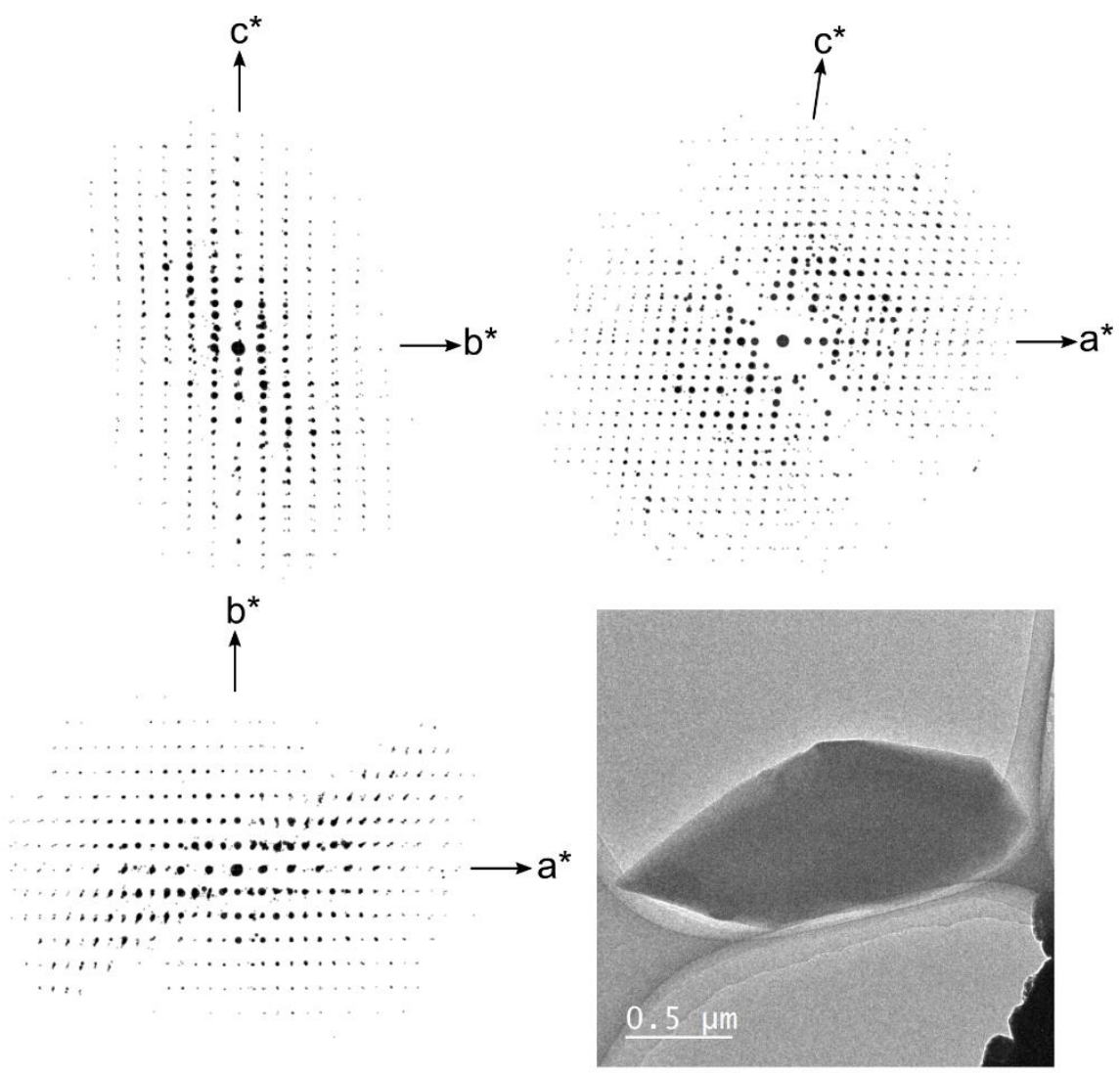

Figure S3. Reciprocal space projections along $a^{*}, b^{*}$ and $c^{*}$, as well as the crystal used for collecting the electron diffraction data on as-synthesized SU-100. 
Table S1: Crystallographic table for electron diffraction data of as-synthesized SU-100.

\begin{tabular}{|c|c|}
\hline Identification code & as-synthesized SU-100 \\
\hline Crystal system & Monoclinic \\
\hline Space group & I2/a (No. 15) \\
\hline \multirow[t]{4}{*}{ Unit cell dimensions } & $a=18.26 \AA$ \\
\hline & $b=10.32 \AA$ \\
\hline & $c=21.55 \AA$ \\
\hline & $\beta=97.2^{\circ}$ \\
\hline Volume $\left(\AA^{3}\right)$ & $4029 \AA^{3}$ \\
\hline Z & 8 \\
\hline Rotation range & $82.34^{\circ}\left(-70.15\right.$ to $\left.12.19^{\circ}\right)$ \\
\hline \multirow[t]{3}{*}{ Index ranges } & $-17 \leq h \leq 20$ \\
\hline & $-9 \leq k \leq 9$ \\
\hline & $-21 \leq I \leq 23$ \\
\hline Reflections collected & 4172 \\
\hline \multirow[t]{2}{*}{ Independent reflections } & 1788 \\
\hline & {$[\mathrm{R}$ (int) $=0.1702]$} \\
\hline $\begin{array}{l}\text { Completeness (to } 1.0 \AA \\
\text { resolution) }\end{array}$ & $80.2 \%$ \\
\hline $\mathrm{R}_{1}(\mathrm{ED}$ model) $[\mathrm{I}>2 \sigma(\mathrm{I})]$ & 0.2151 \\
\hline
\end{tabular}

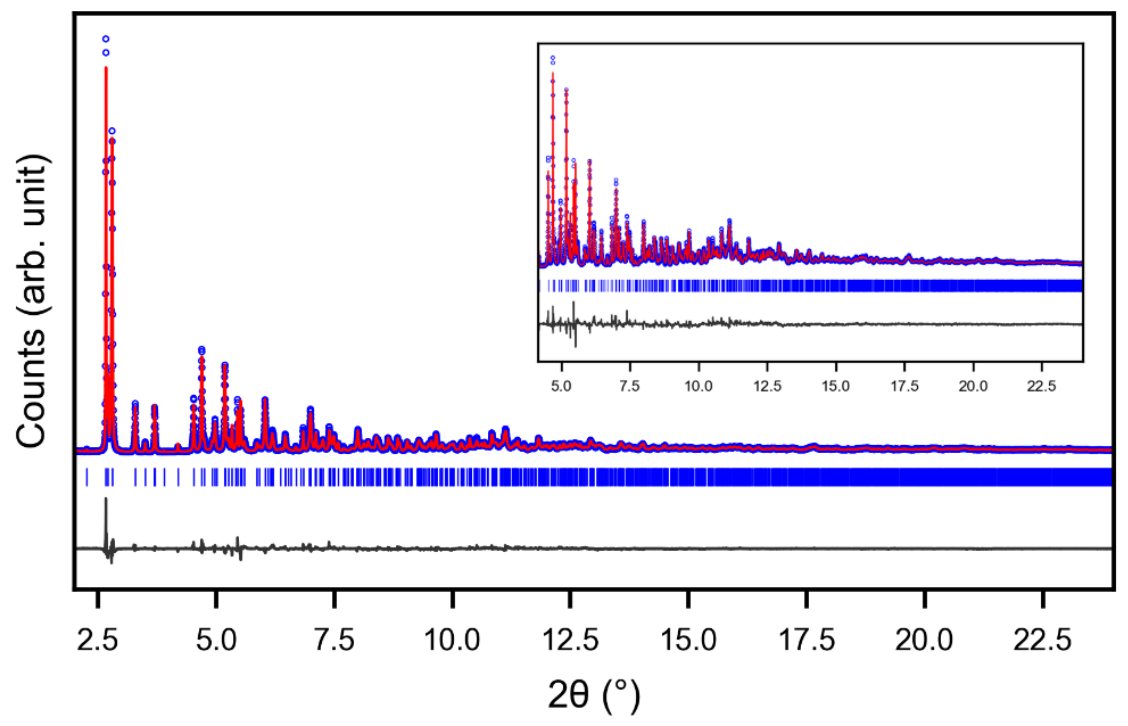

Figure S4. Plot for the refinement of $\mathrm{Bi}(\mathrm{BPT}) \cdot(\mathrm{MeOH})_{2}(\mathrm{SU}-100$, as synthesized). High resolution XRPD data were collected at $11 \mathrm{BM}$ at the APS, Argonne National Laboratory, USA, $\lambda=0.412735 \AA$. 
Table S2. Crystallographic details from X-ray powder diffraction data and structure refinement details for $\mathrm{Bi}(\mathrm{BPT}) \cdot(\mathrm{MeOH})_{2}(\mathrm{SU}-100$, as synthesized).

\begin{tabular}{ll}
\hline Identification code & SU-100, as synthesized \\
Crystal system & Monoclinic \\
Space group & I2/a (No. 15) \\
Unit cell dimensions & $a=17.854(3) \AA$ \\
& $b=9.613(2) \AA$ \\
& $c=21.047(4) \AA$ \\
& $\beta=96.771(2)^{\circ}$ \\
Volume $\left(\AA^{3}\right)$ & $3587(1) \AA^{3}$ \\
Wavelength & $0.412735 \AA$ \\
Refinement method & Profile method \\
Refinement statistics & $R_{\mathrm{wp}}=7.13 \%$ \\
& GOF $=1.75$ \\
\hline
\end{tabular}

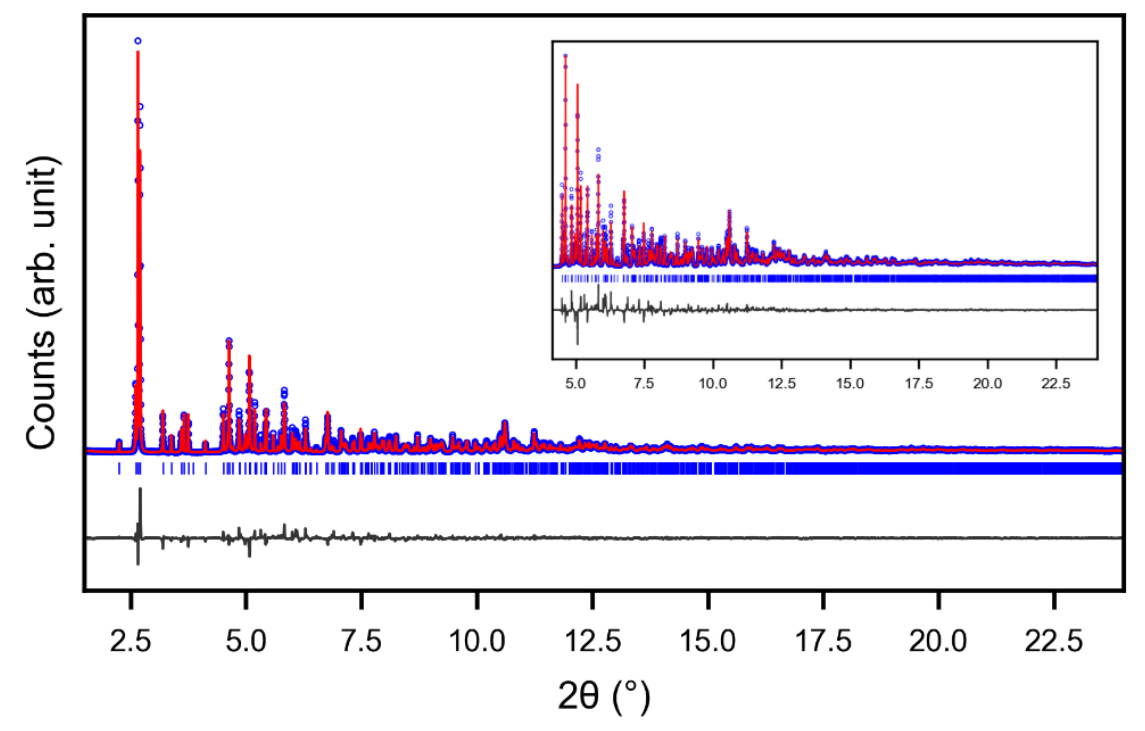

Figure S5. Plot for the refinement of $\mathrm{Bi}(\mathrm{BPT}) \cdot(\mathrm{MeOH})_{3}(\mathrm{MeOH} @ \mathrm{SU}-100)$. High resolution XRPD data were collected at $11 \mathrm{BM}$ at the APS, Argonne National Laboratory, USA, $\lambda=0.412735 \AA$. 
Table S3. Crystallographic details from X-ray powder diffraction data and structure refinement details for $\mathrm{Bi}(\mathrm{BPT}) \bullet(\mathrm{MeOH})_{3}(\mathrm{MeOH} @ \mathrm{SU}-100)$.

\begin{tabular}{ll}
\hline Identification code & SU-100, MeOH \\
Crystal system & Monoclinic \\
Space group & I2/a (No. 15) \\
Unit cell dimensions & $a=18.0213(6) \AA$ \\
& $b=10.0372(4) \AA$ \\
& $C=21.2624(8) \AA$ \\
Volume $\left(\AA^{3}\right)$ & $\beta=99.206(1)^{\circ}$ \\
Wavelength & $3796.5(2) \AA^{3}$ \\
Refinement method & $0.412735 \AA$ \\
Refinement statistics & Profile method \\
& $R_{\mathrm{wp}}=10.46 \%$ \\
\hline
\end{tabular}

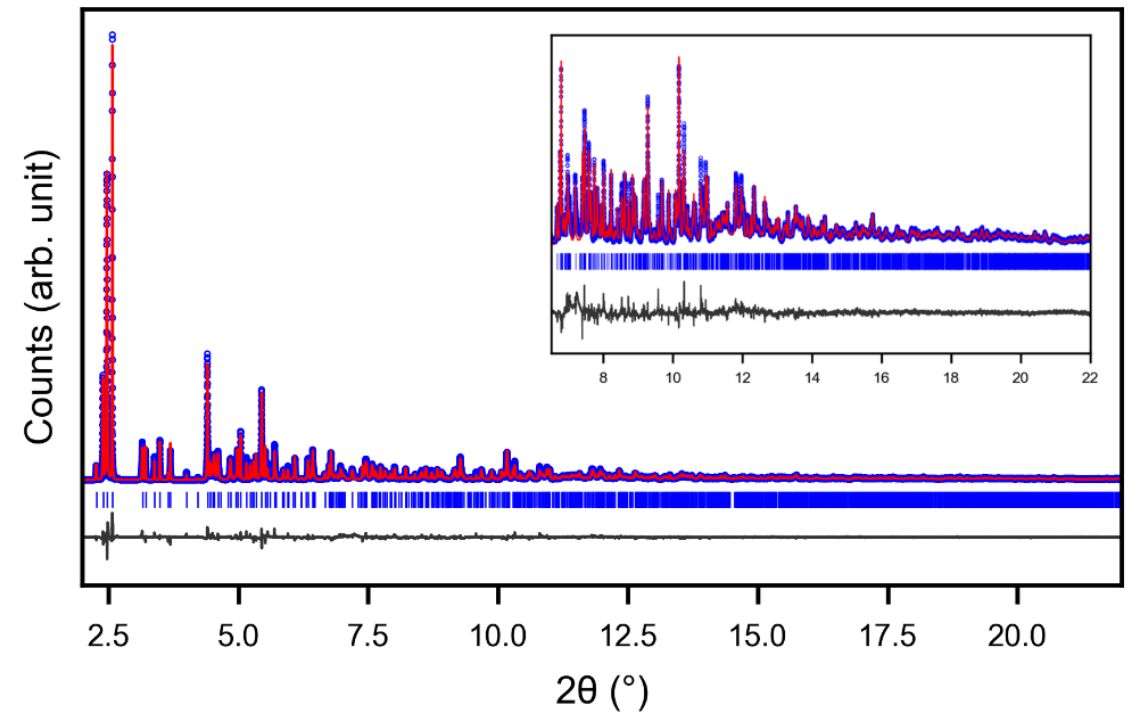

Figure S6. Plot for the refinement of $\mathrm{Bi}(\mathrm{BPT}) \cdot(\mathrm{DEF})$ (DEF@SU-100). High-resolution XRPD data were collected at ID22 at ESRF. Grenoble, France, $\lambda=0.40022674 \AA$. 
Table S4. Crystallographic details from X-ray powder diffraction data and structure refinement details for $\mathrm{Bi}(\mathrm{BPT}) \cdot(\mathrm{DEF})$ (DEF@SU-100).

\begin{tabular}{ll}
\hline Identification code & SU-100-DEF \\
Crystal system & Monoclinic \\
Space group & I2/a (No. 15) \\
Unit cell dimensions & $a=18.018(1) \AA$ \\
& $b=10.8566(8) \AA$ \\
& $c=20.478(1) \AA$ \\
Volume $\left(\AA^{3}\right)$ & $\beta=99.1116(5)^{\circ}$ \\
Wavelength & $3955.5 \AA^{3}$ \\
Refinement method & $0.40022674 \AA$ \\
Refinement statistics & Profile method \\
& $R$ wp $=9.52 \%$ \\
\hline
\end{tabular}
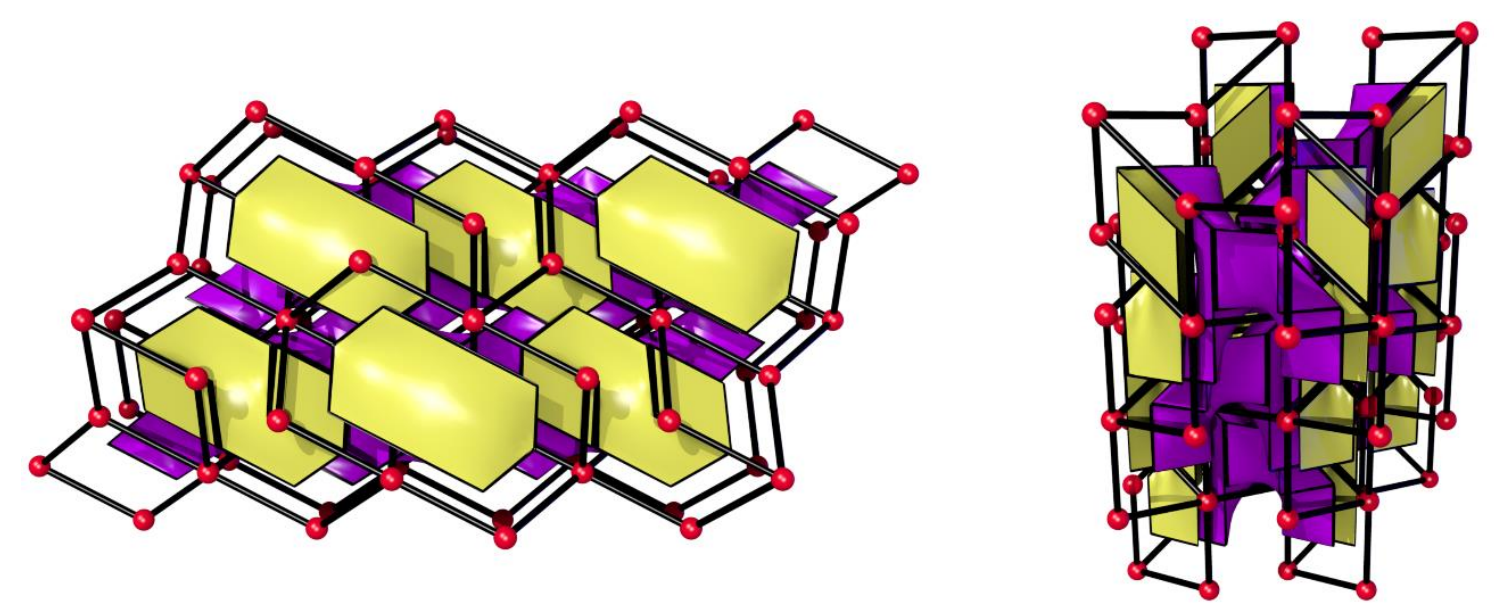

Figure S7. The esg net and the tiling found, showing two kinds of tile (yellow and purple), viewed along [010] (left) and [100] (right). 

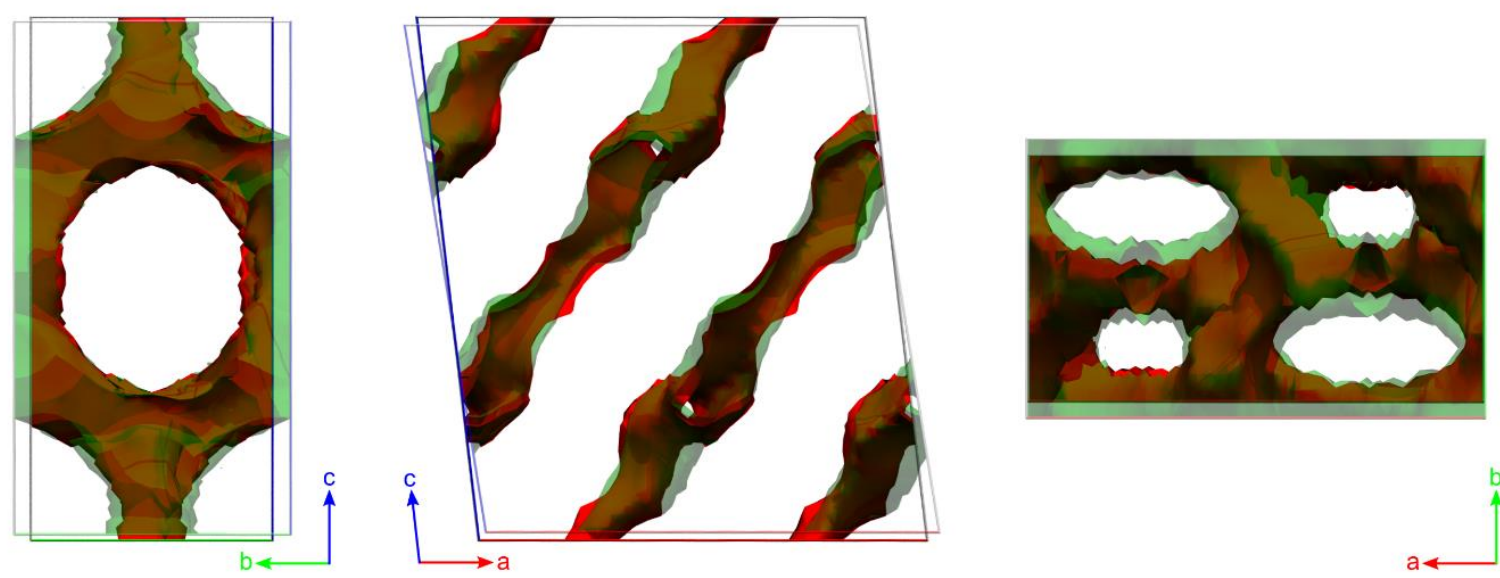

Figure S8. Superimposed figures of the solvent-accessible voids (visualized in MCE2005 ${ }^{1}$ ) for the as-synthesized SU-100 (red) and DEF@SU-100 (green). The views are (from left to right) along [100], [010], and [001]. The solvent accessible void volume increases from $1264 \AA^{3}$ (as-synthesized SU-100) to $1596 \AA^{3}$ (DEF@SU-100). The expansion occurs in all directions, but is most noticeable when viewing the structure in the ab-plane.

Table S5: Crystallographic table for electron diffraction data of SU-100-HT.

\begin{tabular}{cc}
\hline Identification Code & SU-100-HT \\
Wavelength & $0.0251 \AA$ \\
Crystal system & Monoclinic \\
Space group & $I 2 / a$ (No. 15) \\
Unit cell dimensions & $a=19.00 \AA$ \\
& $b=10.57 \AA$ \\
& $c=22.07 \AA$ \\
Volume & $\beta=99.33^{\circ}$ \\
Z & $4373 \AA^{3}$ \\
Rotation range & 8 \\
Index ranges & $110.18^{\circ}\left(-43.04\right.$ to $\left.67.14^{\circ}\right)$ \\
& $-23 \leq h \leq 23$ \\
Reflections collected & $-11 \leq k \leq 11$ \\
Independent reflections & $-27 \leq I \leq 27$ \\
Completeness (to $0.8 \AA$ resolution) & 3064 \\
R1 (ED model) $[I>2 \sigma(I)]$ & 1561 \\
\hline [R(int) $=0.3739]$ \\
$90.03 \%$ \\
0.2949 \\
\hline
\end{tabular}




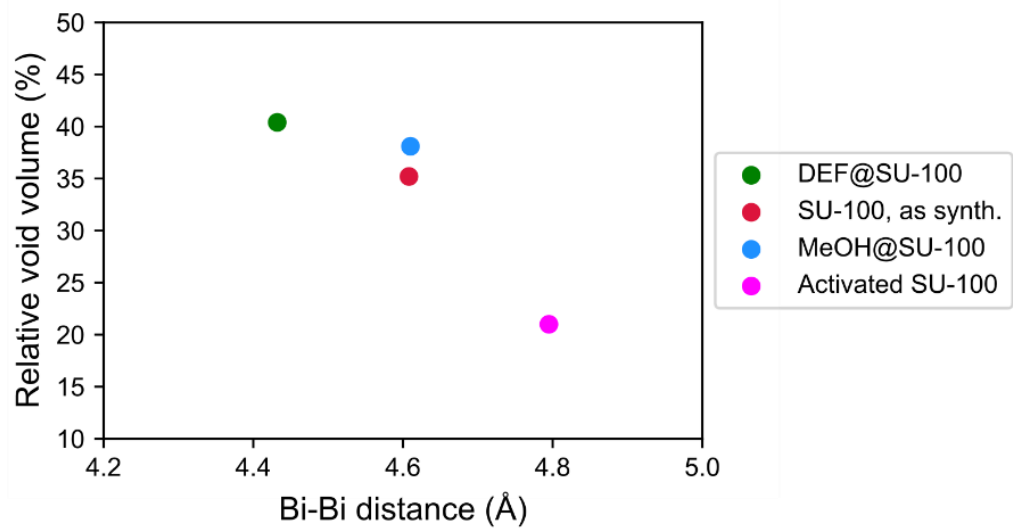

Figure S9. Plot of the calculated void volume (using PLATON's Calc Solv) vs. the Bi-Bi distance in the $\mathrm{Bi}_{2} \mathrm{O}_{12}$ building unit of SU-100

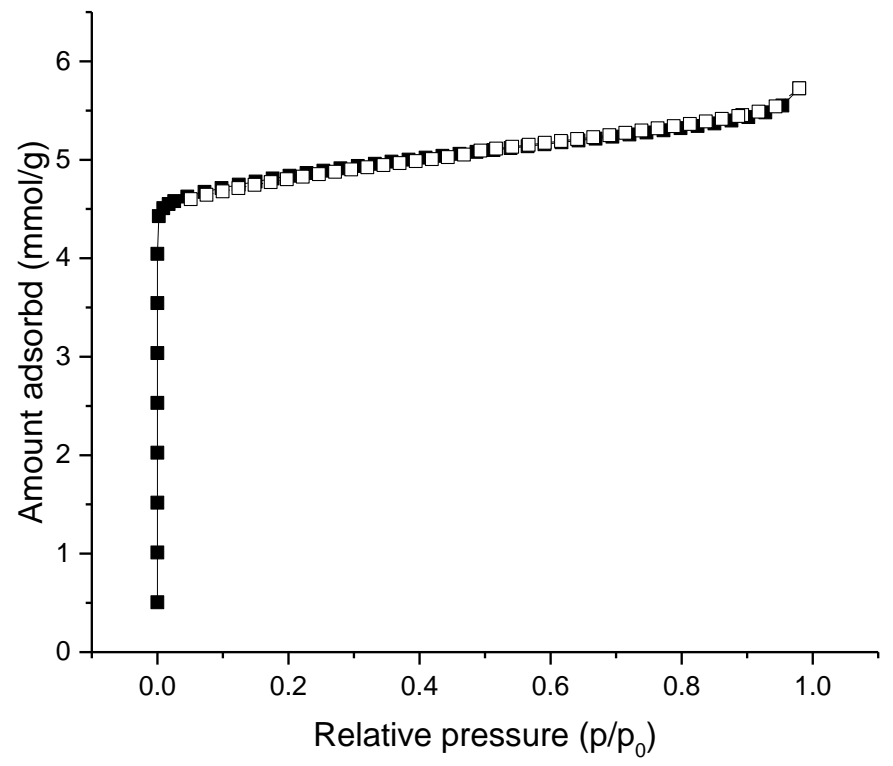

Figure S10. $\mathrm{N}_{2}$ adsorption/desorption isotherm of $\mathrm{SU}-100$ recorded at liquid $\mathrm{N}_{2}$ temperature. BET surface area: $385 \mathrm{~m}^{2} / \mathrm{g}$. Langmuir surface area: $483 \mathrm{~m}^{2} / \mathrm{g}$. 


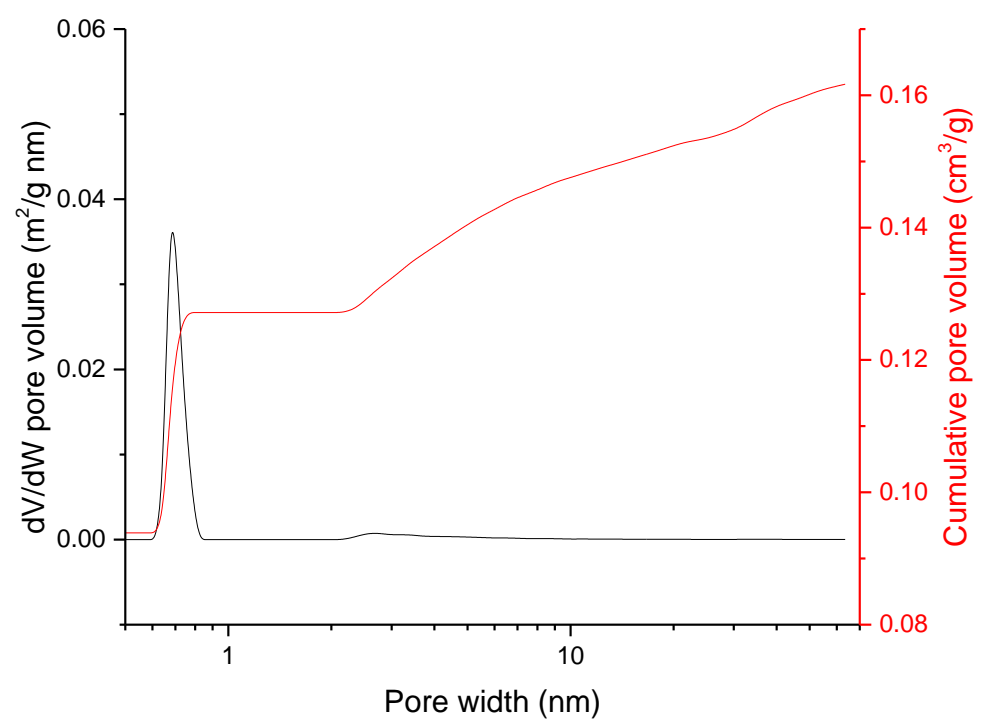

Figure S11. DFT pore size distribution of SU-100.

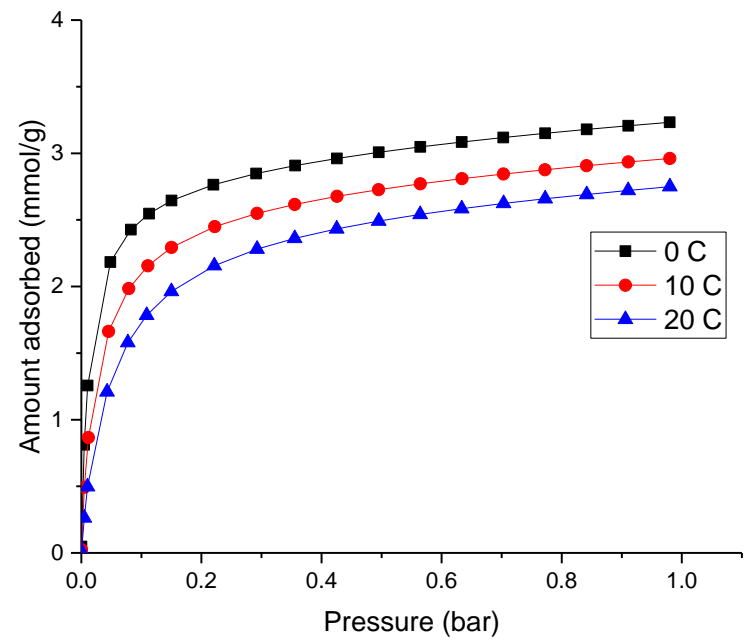

Figure S12. $\mathrm{CO}_{2}$ adsorption isotherms of $\mathrm{SU}-100$ recorded at 0,10 and $20^{\circ} \mathrm{C}$ 


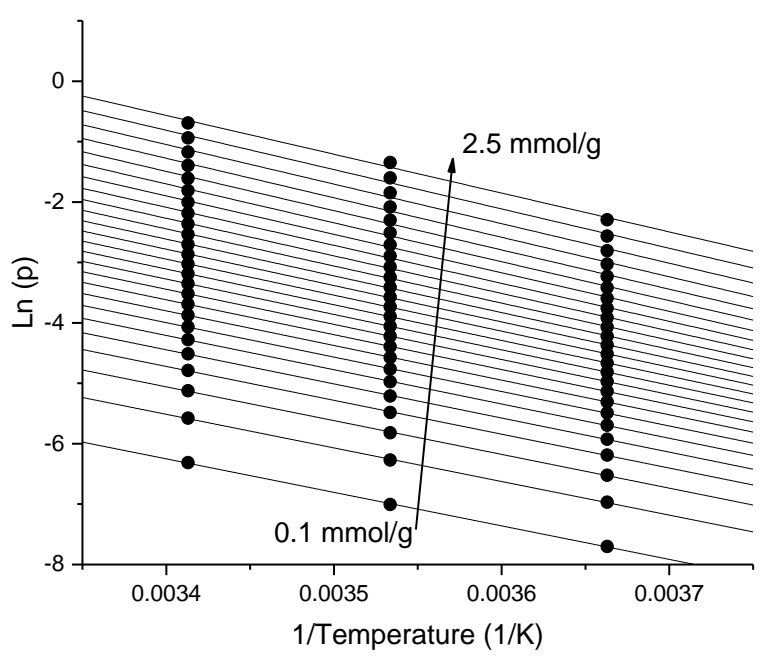

Figure S13. Plot of $\operatorname{In}(\mathrm{P})$ versus $1 / \mathrm{T}$ for $\mathrm{CO}_{2}$ adsorption on SU-100. The heat of adsorption can be calculated from the slope of these lines according to the Clausius-Clapeyron equation.

The heat of $\mathrm{CO} 2$ adsorption verses loading on SU-100 was calculated using the Clausius-Clapeyron equation

$$
\frac{d \ln (P)}{d\left(\frac{1}{T}\right)}=-\frac{E_{a d s}}{R}
$$

where $\mathrm{P}$ is the pressure at a particular level of $\mathrm{CO}_{2}$ loading, $\mathrm{T}$ is temperature in $\mathrm{K}, \mathrm{R}$ is the ideal gas constant and $\mathrm{E}_{\text {ads }}$ is the heat of $\mathrm{CO}_{2}$ adsorption. The data used is shown in Figure $\mathrm{S} 13$. The $\mathrm{CO}_{2}$ adsorption isotherms shown in Figure $\mathrm{S} 12$ were fitted using the two side Langmuir isotherm model. The fitted Langmuir equation at for each isotherm (at 0,10 and $20^{\circ} \mathrm{C}$ ) was used to calculate the equilibrium pressures $(\mathrm{P})$ at $\mathrm{CO}_{2}$ loading between 0.1 and $2.5 \mathrm{mmol} / \mathrm{g}$ at the corresponding temperature. The slope of the $\ln (\mathrm{P}) \mathrm{vs}$. $1 / \mathrm{T}$ plot shown in Figure $\mathrm{S} 13$ was fitted with straight lines and the slope of the lines were used to calculate the heat of $\mathrm{CO}_{2}$ adsorption versus loading. The calculated heat of $\mathrm{CO}_{2}$ sorption between 0.1 and $2.5 \mathrm{mmol} / \mathrm{g}$ loading is shown in Figure S14. The heat of $\mathrm{CO}_{2}$ adsorption on SU-100 was around $45-55 \mathrm{~kJ} / \mathrm{mol}$ 


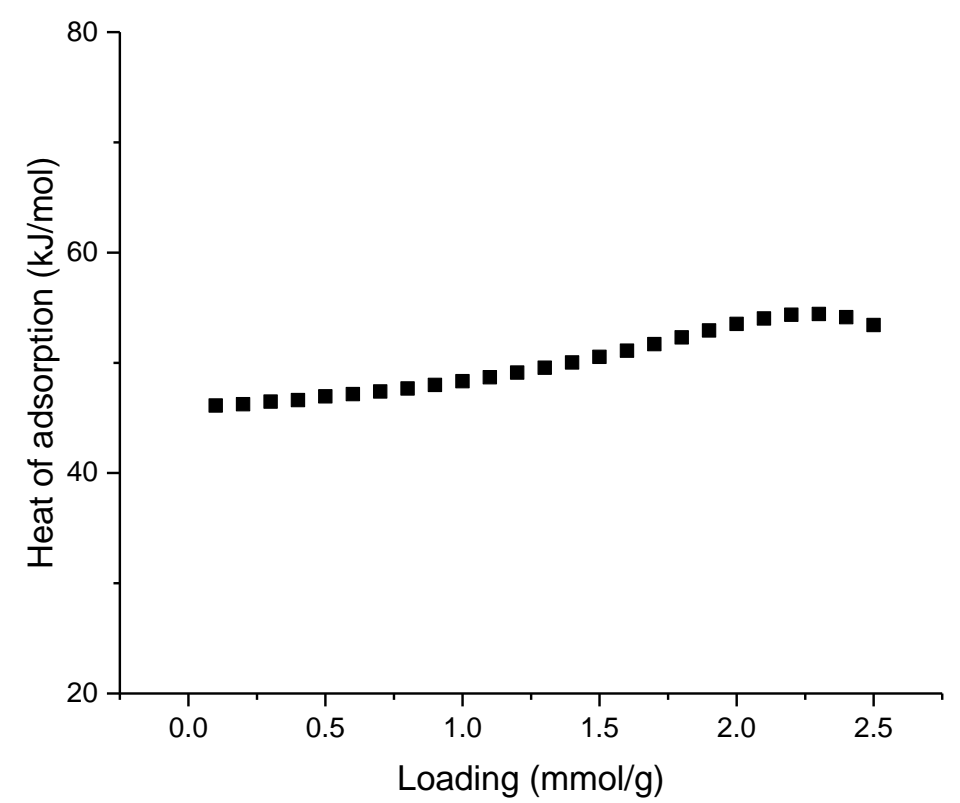

Figure S14. Heat of $\mathrm{CO}_{2}$ adsorption on $\mathrm{SU}-100$ calculated using the Clausius-Clapeyron equation.

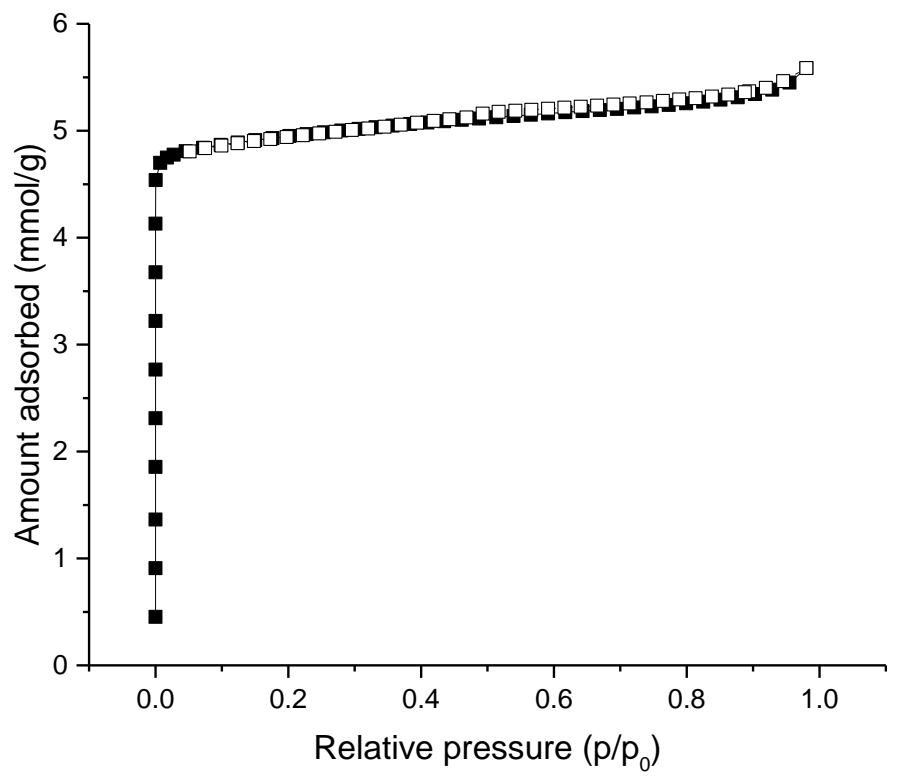

Figure S15. $\mathrm{N}_{2}$ adsorption/desorption isotherm of $\mathrm{SU}-100$ soaked in water (100 ${ }^{\circ} \mathrm{C}, 1$ hour) recorded at liquid $\mathrm{N}_{2}$ temperature. BET surface area: $395 \mathrm{~m}^{2} / \mathrm{g}$. Langmuir surface area: $484 \mathrm{~m}^{2} / \mathrm{g}$. 


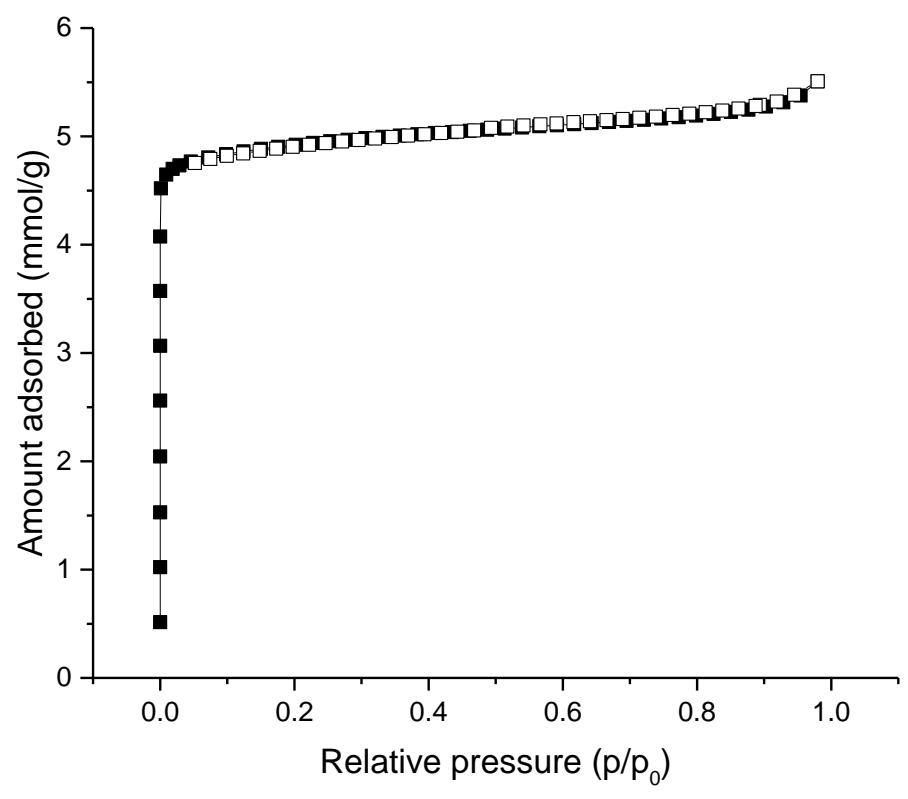

Figure S16. $\mathrm{N}_{2}$ adsorption/desorption isotherm of $\mathrm{SU}-100$ soaked in toluene $\left(100{ }^{\circ} \mathrm{C}, 1\right.$ hour) recorded at liquid $\mathrm{N}_{2}$ temperature. BET surface area: $393 \mathrm{~m}^{2} / \mathrm{g}$. Langmuir surface area: $482 \mathrm{~m}^{2} / \mathrm{g}$. 


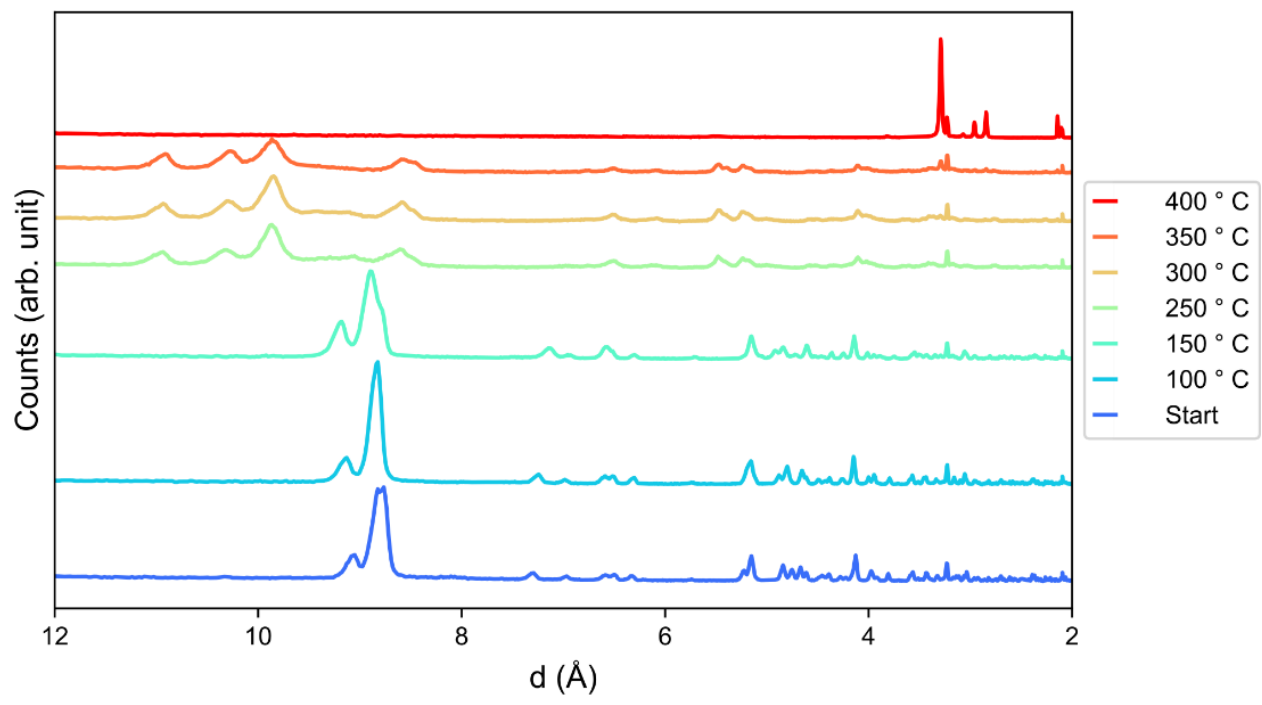

Figure S17. Thermodiffraction measurements of SU-100 in air, showing that large structural changes start to occur above $150{ }^{\circ} \mathrm{C}$. Above $350{ }^{\circ} \mathrm{C}$, the organic material seems to be lost and $\mathrm{Bi}_{2} \mathrm{O}_{3}$ is acquired.

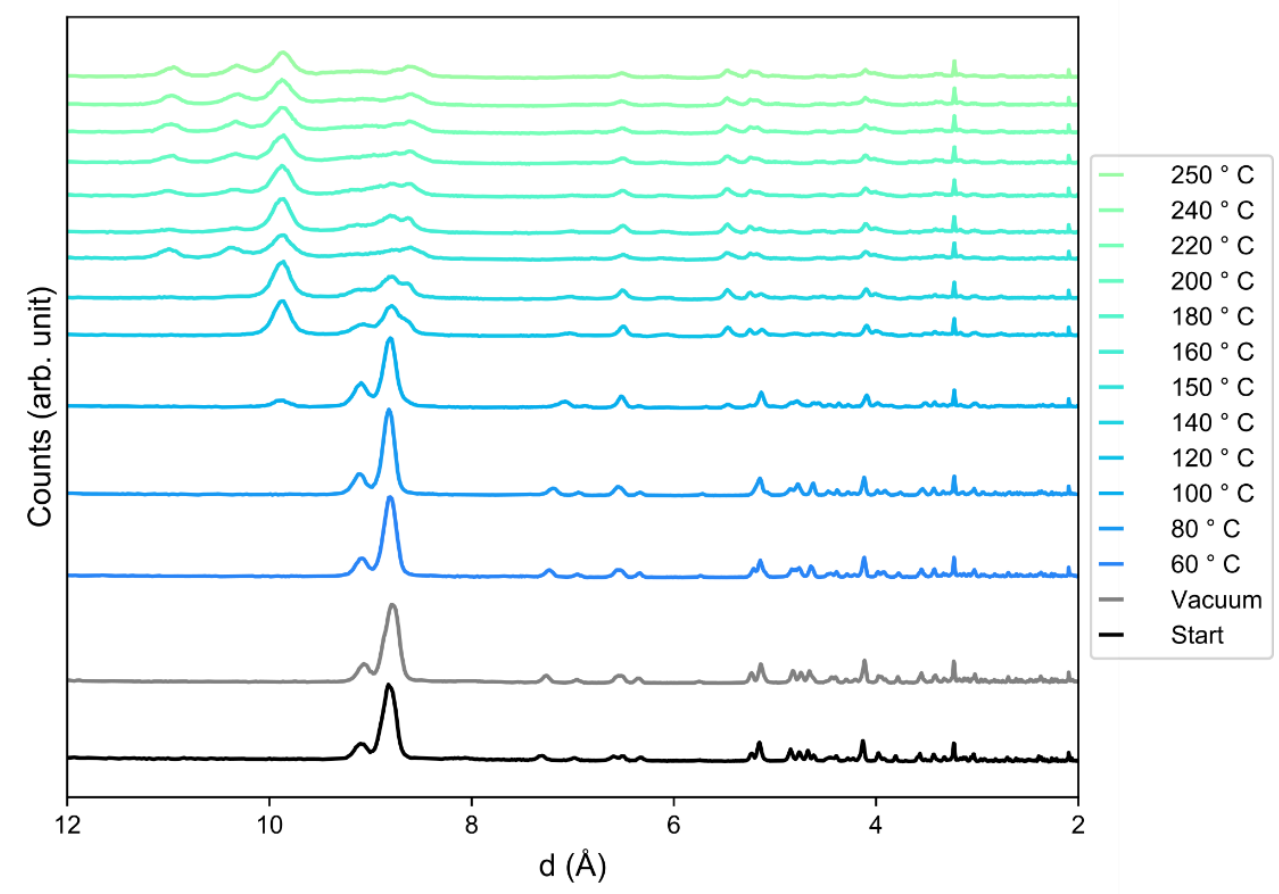

Figure S18. Thermodiffraction measurements of SU-100 under reduced pressure ( 0.1 bar), showing a virtually unchanged diffraction pattern up to $100^{\circ} \mathrm{C}$. Above $100^{\circ} \mathrm{C}$, large structural changes occur and the strong reflection around $9 \AA$ is gradually lost with increasing temperature. Post-thermodiffraction, the sample was placed in isopropanol, regaining crystallinity (see Figure S19). 


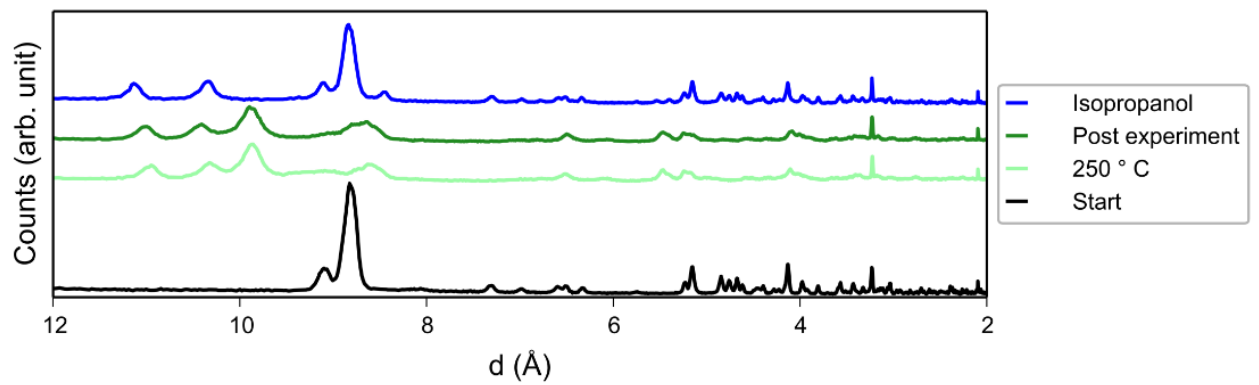

Figure S19. X-ray powder diffraction data on as-synthesized SU-100 (Start), which was then heated to $250{ }^{\circ} \mathrm{C}$, and cooled down to room temperature (Post experiment). A drop of isopropanol was then placed onto the postthermodiffraction (room temperature and atmospheric pressure) sample of SU-100, showing a diffraction pattern which is somewhat similar to the as-synthesized material. Two additional low-angle peaks are seen. The origin of these two peaks has not been investigated but is suspected to be from an unidentified phase.

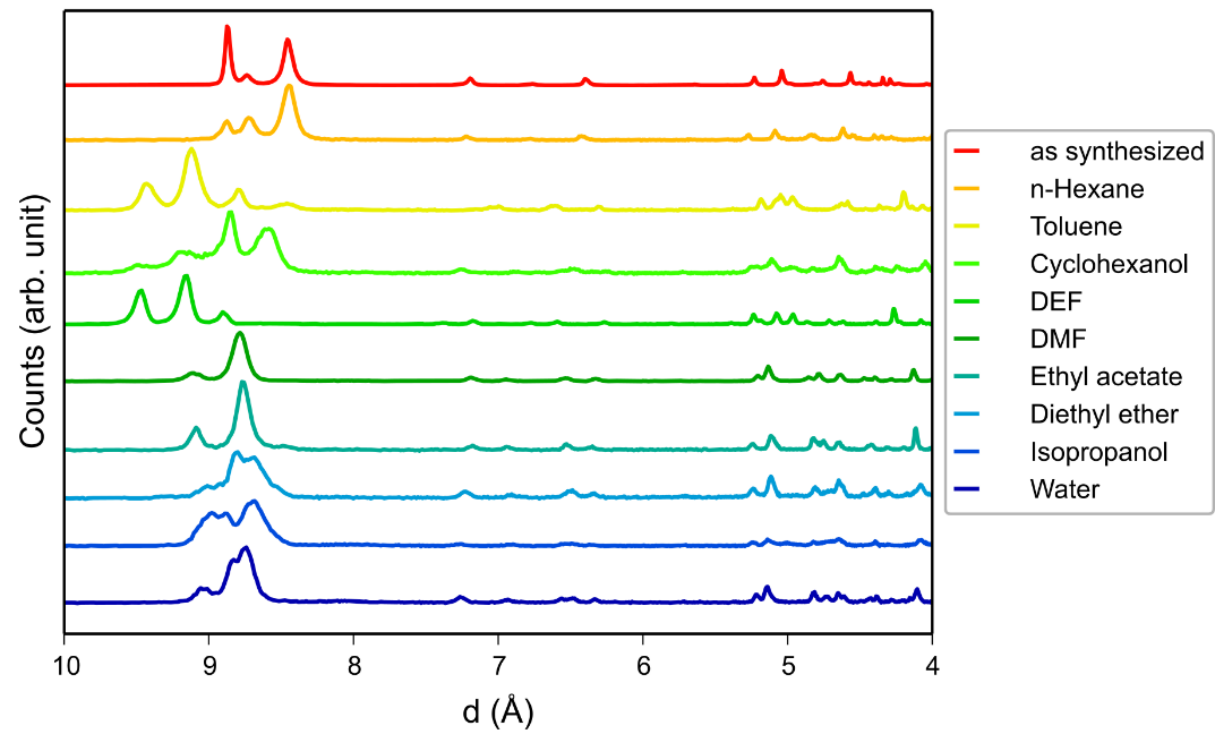

Figure S20. Acquired diffractograms of SU-100 after being immersed in various solvents for 24 hours at room temperature. Branched solvents with more than four non-hydrogen atoms seems to give an apparent increase in the unit cell volume. 


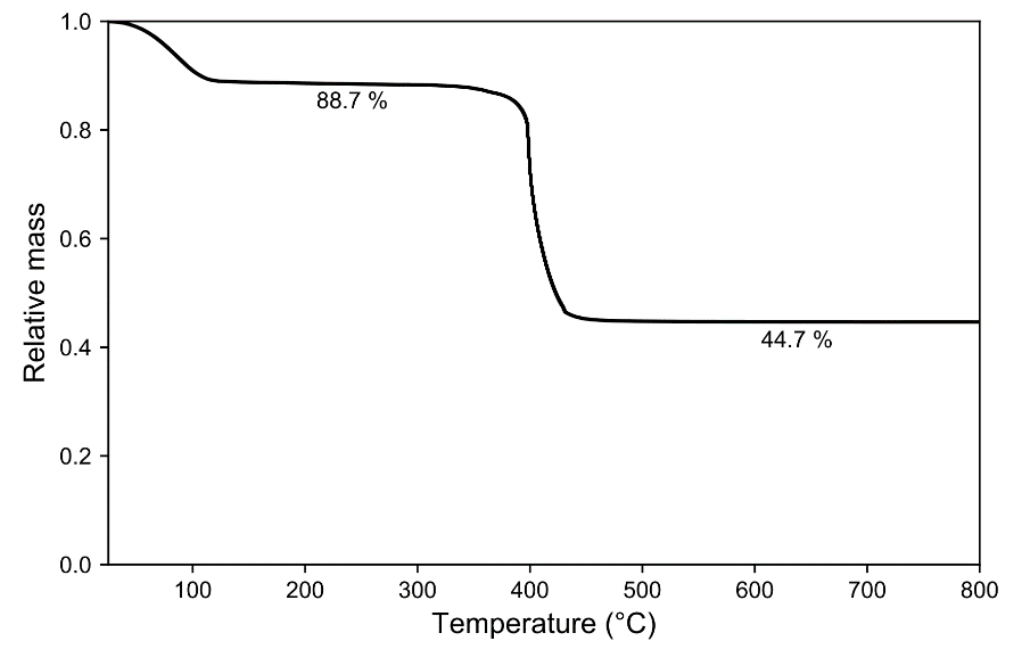

Figure S21. Results from a thermogravimetric analysis of SU-100, showing a weight-loss of $11.3 \%$ from $50-120$ ${ }^{\circ} \mathrm{C}$, matching well with the expected value for two methanol molecules per asymmetric unit (11.5 wt.\%). The second weight-loss step of $44.0 \%$ occurs between $350-450{ }^{\circ} \mathrm{C}$ ( $46.6 \%$ expected), where the higher-thanexpected remaining mass could be due to unreacted bismuth-species. 


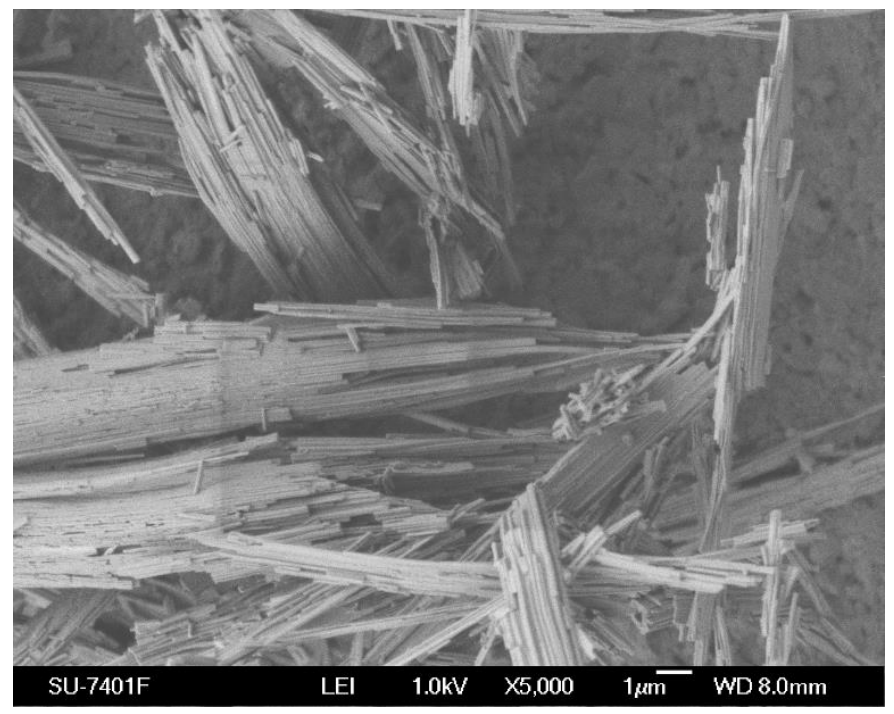

Figure S22. SEM micrograph of $\mathrm{Bi}_{2} \mathrm{O}_{2}(\mathrm{HBPT})$ (2), showing aggregates of needle-shaped crystals.

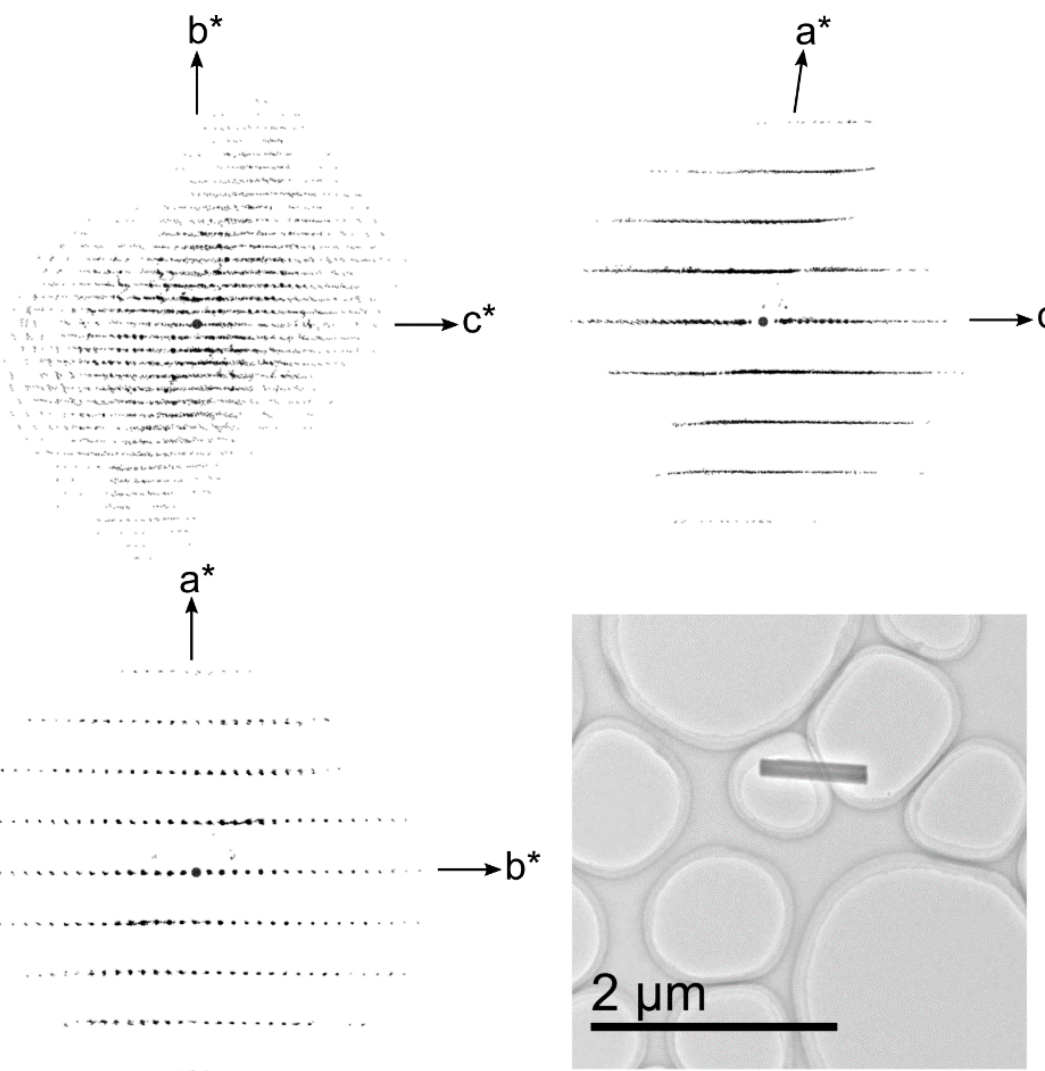

Figure S23. Reciprocal space projections along $\mathrm{a}^{*}, \mathrm{~b}^{*}$ and $\mathrm{c}^{*}$, as well as the crystal used for electron diffraction data collection for $\mathrm{Bi}_{2} \mathrm{O}_{2}(\mathrm{HBPT})$ (2). 
Table S6: Crystallographic table for electron diffraction data of $\mathrm{Bi}_{2} \mathrm{O}_{2}(\mathrm{HBPT})(2)$.

\begin{tabular}{|c|c|}
\hline Identification Code & $\mathrm{Bi}_{2} \mathrm{O}_{2}(\mathrm{HBPT})$ \\
\hline Wavelength & $0.0251 \AA$ \\
\hline Crystal system & Monoclinic \\
\hline Space group & $P 2{ }_{1} / c$ (No. 14) \\
\hline \multirow[t]{4}{*}{ Unit cell dimensions } & $a=3.99 \AA$ \\
\hline & $b=15.49 \AA$ \\
\hline & $c=26.15 \AA$ \\
\hline & $\beta=91.66^{\circ}$ \\
\hline Volume & $4373 \AA^{3}$ \\
\hline Z & 4 \\
\hline Rotation range & $112.2^{\circ}\left(-53.0\right.$ to $\left.59.2^{\circ}\right)$ \\
\hline \multirow[t]{3}{*}{ Index ranges } & $-4 \leq h \leq 4$ \\
\hline & $-18 \leq k \leq 18$ \\
\hline & $-32 \leq 1 \leq 32$ \\
\hline Reflections collected & 6944 \\
\hline \multirow[t]{2}{*}{ Independent reflections } & 2548 \\
\hline & {$[R($ int $)=0.1626]$} \\
\hline Completeness (to $0.8 \AA$ resolution) & $89.9 \%$ \\
\hline $\mathrm{R}_{1}(\mathrm{ED}$ model) $[\mathrm{I}>2 \sigma(\mathrm{I})]$ & 0.4299 \\
\hline
\end{tabular}

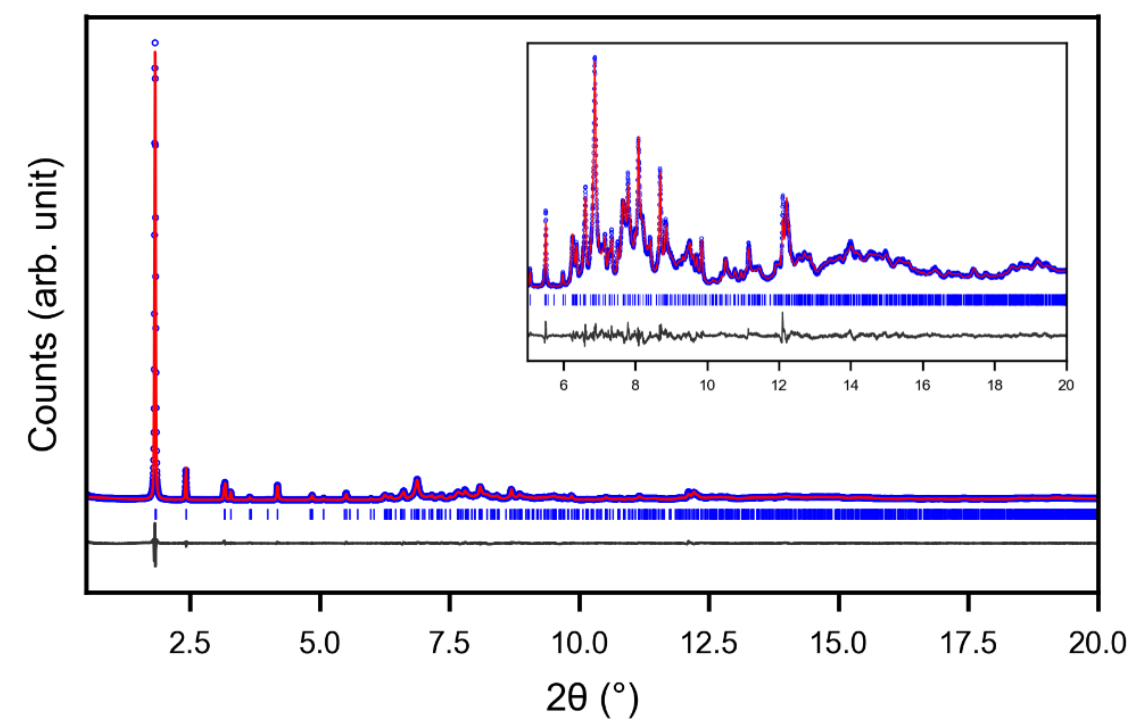

Figure S24. Plot for the structure refinement of $\mathrm{Bi}_{2} \mathrm{O}_{2}(\mathrm{HBPT})$ (2). High resolution XRPD data were collected at $11 \mathrm{BM}$ at the APS, Argonne National Laboratory, USA, $\lambda=0.412735 \AA$. 
Table S7. Crystallographic details from X-ray powder diffraction data and structure refinement details for $\mathrm{Bi}_{2} \mathrm{O}_{2}$ (HBPT) (2).

\begin{tabular}{ll}
\hline Identification code & $\mathrm{Bi}_{2} \mathrm{O}_{2}(\mathrm{HBPT})(2)$ \\
Crystal system & Monoclinic \\
Space group & $P 2_{1} / c($ No. 14$)$ \\
Unit cell dimensions & $a=3.9144(6) \AA$ \\
& $b=15.015(2) \AA$ \\
& $c=25.767(4) \AA$ \\
Volume $\left(\AA^{3}\right)$ & $\beta=91.645(8)^{\circ}$ \\
Wavelength & $1513.8(4) \AA^{3}$ \\
Refinement method & $0.412735 \AA$ \\
Refinement statistics & Profile method \\
& $R_{\mathrm{wp}}=6.35 \%$ \\
\hline
\end{tabular}

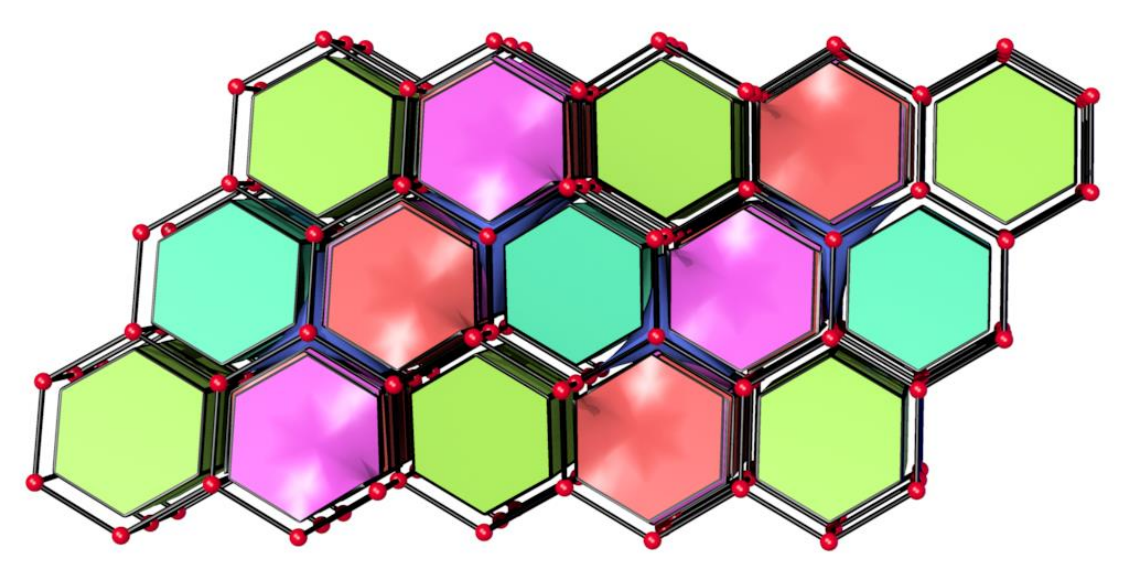

Figure S25. Tiling found for $\mathbf{2}$ when the organic part is represented as a single 3-c node, viewed slightly off-axis of the [100] direction. The net found has a transitivity of 3685 . 


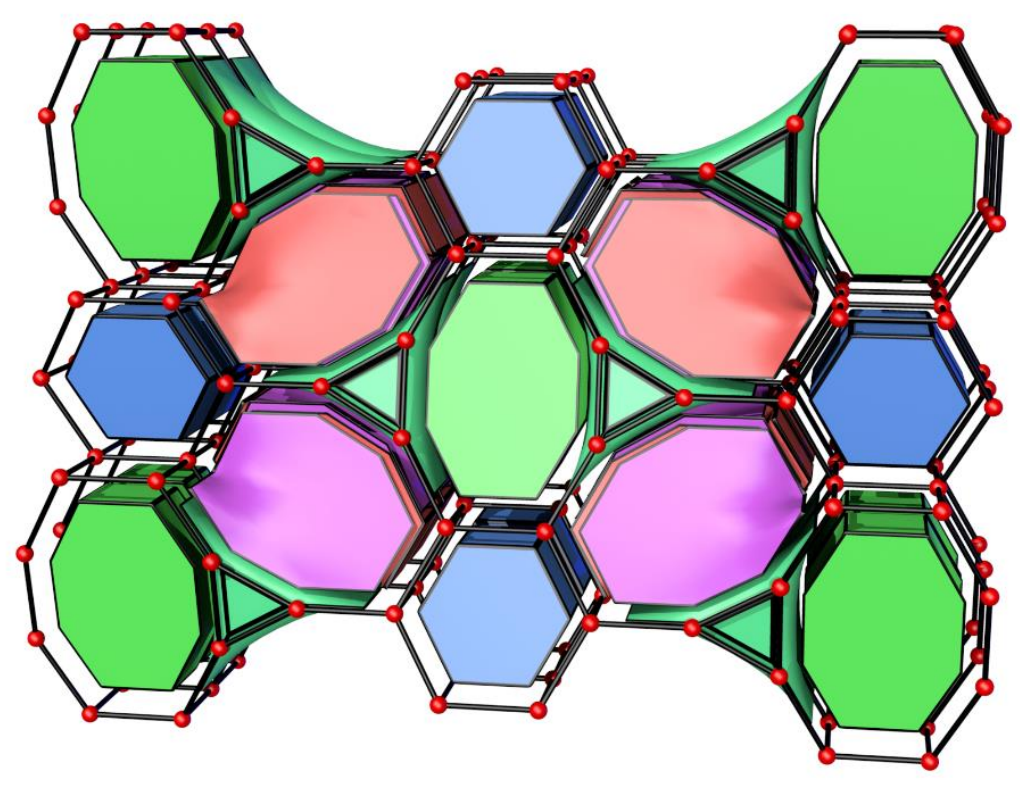

Figure S26. Tiling found for $\mathbf{2}$ when the organic part is represented as three 3-c nodes, viewed slightly off-axis of the [100] direction. The net found has a transitivity of $6(12)(13) 7$.

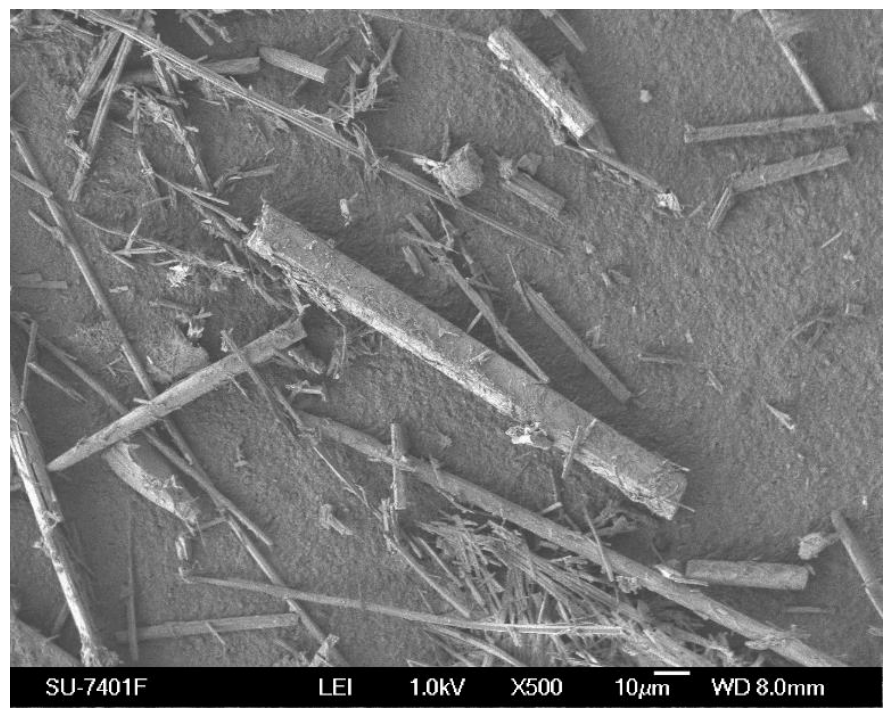

Figure S27. SEM micrograph of $\mathrm{Bi}(\mathrm{OH})\left(\mathrm{H}_{2} \mathrm{BPT}\right)_{2}\left(\mathrm{H}_{2} \mathrm{O}\right)_{2} \cdot \mathrm{H}_{2} \mathrm{O}(\mathbf{3})$, showing large bladed crystals together with small amounts of 2 . 


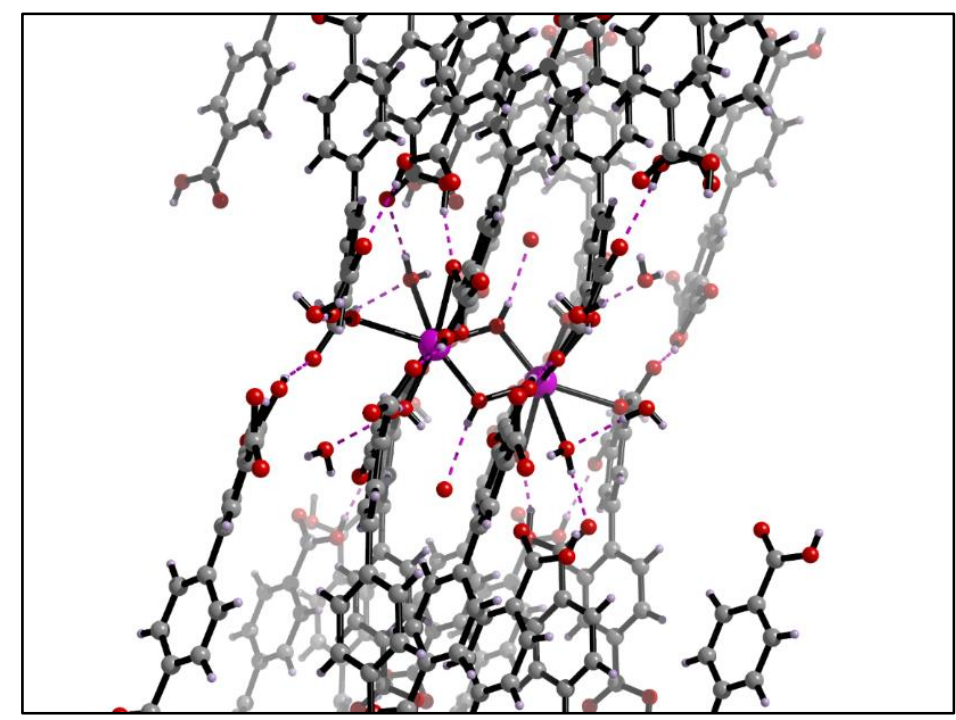

Figure S28. Image showing hydrogen bonds in $\mathrm{Bi}(\mathrm{OH})\left(\mathrm{H}_{2} \mathrm{BPT}\right)_{2}\left(\mathrm{H}_{2} \mathrm{O}\right)_{2} \cdot \mathrm{H}_{2} \mathrm{O}(\mathbf{3}) . \mathrm{O} \cdots \mathrm{H}$ distances between 1.8 and $2.2 \AA$ are shown in dashed purple lines.

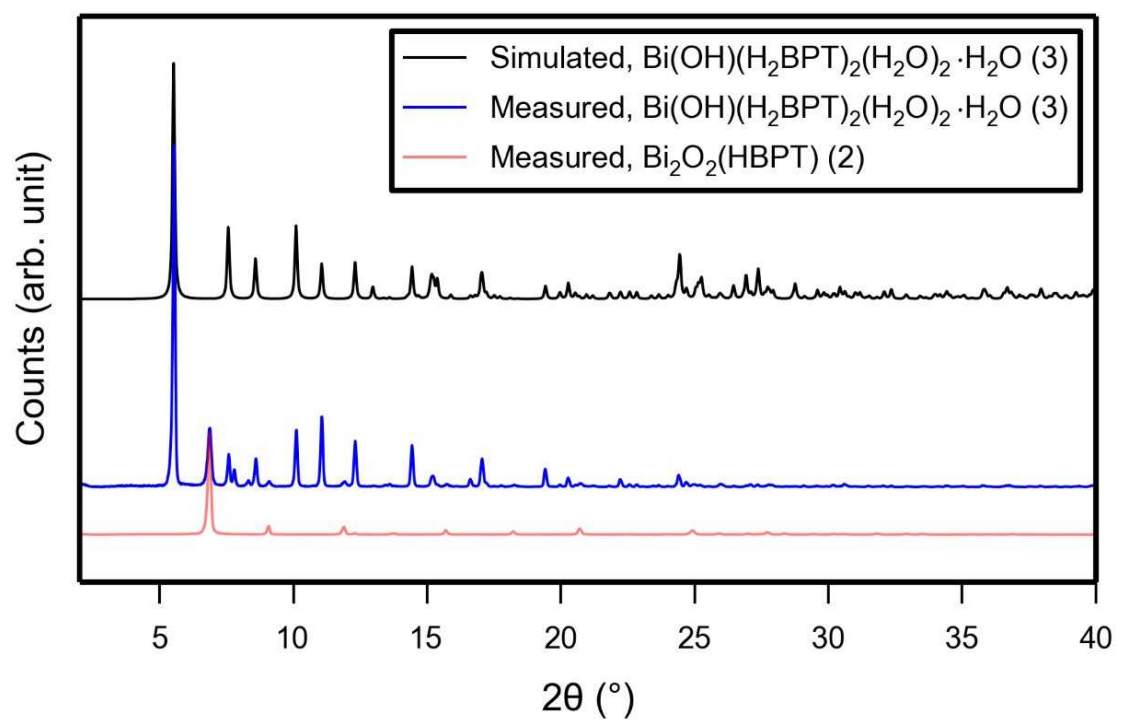

Figure S29. Measured and simulated powder pattern for $\mathrm{Bi}(\mathrm{OH})\left(\mathrm{H}_{2} \mathrm{BPT}\right)_{2}\left(\mathrm{H}_{2} \mathrm{O}\right)_{2} \cdot \mathrm{H}_{2} \mathrm{O}(\mathbf{3})$, apprehended as a mixture with 2, as seen by the measured powder pattern for 3 . There also is a small amount of 4 present (additional reflection around $2 \theta=8^{\circ}$ ). 
Table S8. Crystallographic table for single crystal $\mathrm{X}$-ray diffraction data and structure refinement details for $\mathrm{Bi}(\mathrm{OH})\left(\mathrm{H}_{2} \mathrm{BPT}\right)_{2}\left(\mathrm{H}_{2} \mathrm{O}\right)_{2} \cdot \mathrm{H}_{2} \mathrm{O}(3)$.

\begin{tabular}{|c|c|}
\hline Identification code & $\mathrm{Bi}(\mathrm{OH})\left(\mathrm{H}_{2} \mathrm{BPT}\right)_{2}\left(\mathrm{H}_{2} \mathrm{O}\right)_{2} \cdot \mathrm{H}_{2} \mathrm{O}(\mathbf{3})$ \\
\hline Empirical formula & $\mathrm{C}_{30} \mathrm{H}_{23} \mathrm{BiO}_{16}$ \\
\hline Formula weight & $848.46 \mathrm{~g} \mathrm{~mol}^{-1}$ \\
\hline Temperature & $295(2) \mathrm{K}$ \\
\hline Wavelength & $0.71073 \AA$ \\
\hline Crystal system & Triclinic \\
\hline Space group & $P \overline{1}$ (No. 2) \\
\hline \multirow[t]{6}{*}{ Unit cell dimensions } & $a=7.3959(3) \AA$ \\
\hline & $b=11.9364(4) \AA$ \\
\hline & $c=16.2328(5) \AA$ \\
\hline & $\alpha=99.343(2)^{\circ}$ \\
\hline & $\beta=92.285(2)^{\circ}$ \\
\hline & $\gamma=97.253(2)^{\circ}$ \\
\hline Volume & $1400.04(9) \AA^{3}$ \\
\hline Z & 2 \\
\hline Density (calc.) & $2.013 \mathrm{~g} \mathrm{~cm}^{-3}$ \\
\hline Absorption coefficient & $6.383 \mathrm{~mm}^{-1}$ \\
\hline$F(000)$ & 828 \\
\hline Crystal size & $0.20 \times 0.02 \times 0.02 \mathrm{~mm}^{3}$ \\
\hline$\theta$ range for data collection & 2.328 to $27.215^{\circ}$ \\
\hline \multirow[t]{3}{*}{ Index ranges } & $-9 \leq h \leq 9$ \\
\hline & $-15 \leq k \leq 15$ \\
\hline & $-20 \leq I \leq 20$ \\
\hline Reflections collected & 51476 \\
\hline \multirow[t]{2}{*}{ Independent reflections } & 6246 \\
\hline & {$[\mathrm{R}(\mathrm{int})=0.1146]$} \\
\hline Absorption correction & Multi-scan \\
\hline Min. and max. transmission & 0.5958 and 0.7460 \\
\hline Data / restr. / param. & $6246 / 2 / 493$ \\
\hline Goodness-of-fit on $\mathrm{F}^{2}$ & 1.042 \\
\hline \multirow[t]{2}{*}{ Final R indices $[\mathrm{I}>2 \sigma(\mathrm{I})]$} & $R 1=0.0316$ \\
\hline & $w R 2=0.0580$ \\
\hline Largest diff. peak and hole & 1.285 and -0.970 e $\AA^{-3}$ \\
\hline
\end{tabular}




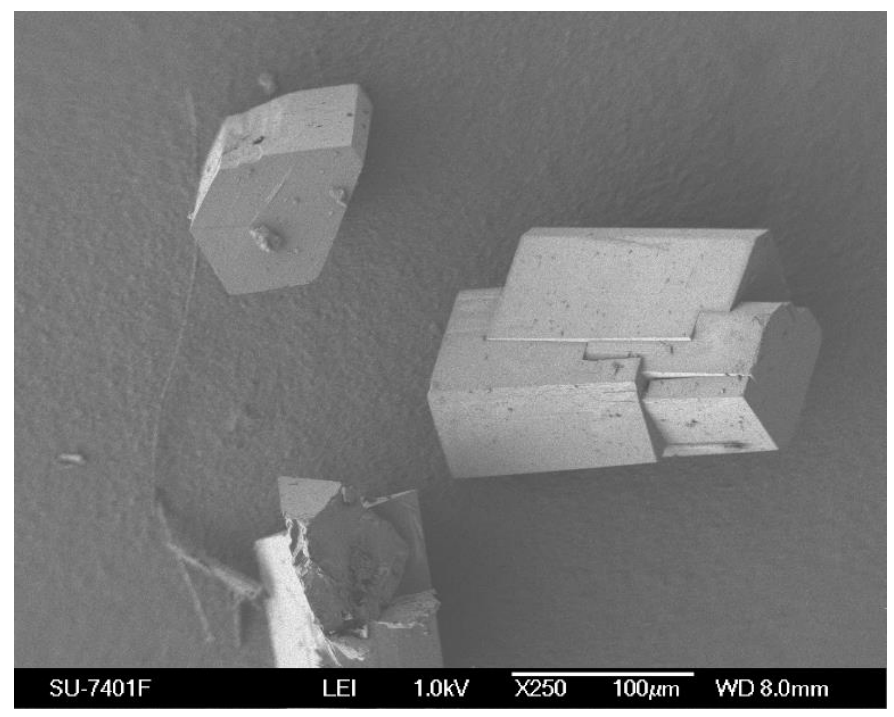

Figure S30. SEM micrograph of $\mathrm{Bi}_{2}(\mathrm{HBPT})_{3}\left(\mathrm{H}_{2} \mathrm{O}\right)_{3} \bullet \mathrm{H}_{3} \mathrm{BPT}(4)$, showing large prismatic crystals.

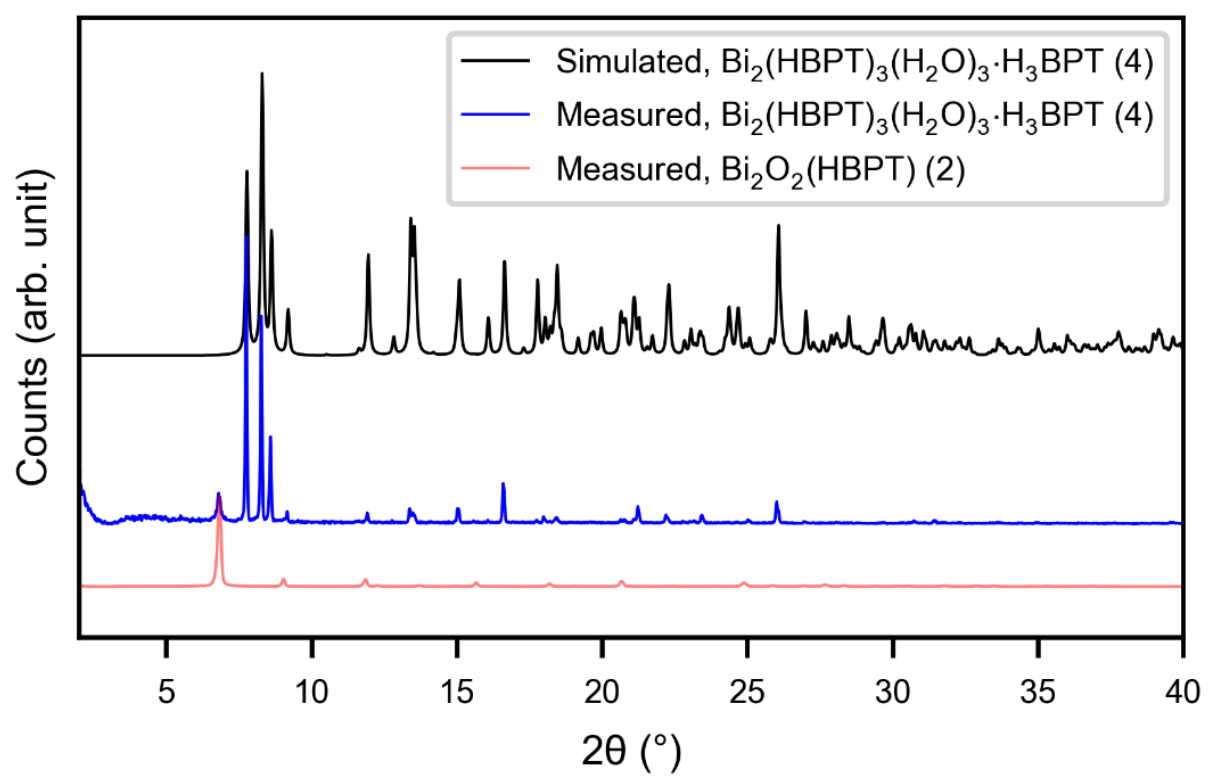

Figure S31. Measured and simulated powder pattern for $\mathrm{Bi}_{2}(\mathrm{HBPT})_{3}\left(\mathrm{H}_{2} \mathrm{O}\right)_{3} \bullet \mathrm{H}_{3} \mathrm{BPT}(4)$, apprehended as a mixture with 2. 
Table S9. Crystallographic table for single crystal X-ray diffraction data and structure refinement for $\mathrm{Bi}_{2}(\mathrm{HBPT})_{3}\left(\mathrm{H}_{2} \mathrm{O}\right)_{3} \cdot \mathrm{H}_{3} \mathrm{BPT}(4)$.

\begin{tabular}{|c|c|}
\hline Identification code & $\mathrm{Bi}_{2}(\mathrm{HBPT})_{3}\left(\mathrm{H}_{2} \mathrm{O}\right)_{3} \cdot \mathrm{H}_{3} \mathrm{BPT}(4)$ \\
\hline Empirical formula & $\mathrm{C}_{60} \mathrm{H}_{34} \mathrm{Bi}_{2} \mathrm{O}_{27}$ \\
\hline Formula weight & $1604.83 \mathrm{~g} \mathrm{~mol}^{-1}$ \\
\hline Temperature & $294(2) \mathrm{K}$ \\
\hline Wavelength & $0.71073 \AA$ \\
\hline Crystal system & Triclinic \\
\hline Space group & $P 1$ (No. 1 ) \\
\hline \multirow[t]{6}{*}{ Unit cell dimensions } & $a=9.9074(4) \AA$ \\
\hline & $b=11.7713(6) \AA$ \\
\hline & $c=12.9136(7) \AA$ \\
\hline & $\alpha=64.992(2)^{\circ}$ \\
\hline & $\beta=76.477(2)^{\circ}$ \\
\hline & $\gamma=87.906(2)^{\circ}$ \\
\hline Volume & $1323.7(1) \AA^{3}$ \\
\hline Z & 1 \\
\hline Density (calc.) & $2.013 \mathrm{~g} \mathrm{~cm}^{-3}$ \\
\hline Absorption coefficient & $6.738 \mathrm{~mm}^{-1}$ \\
\hline$F(000)$ & 776 \\
\hline Crystal size & $0.20 \times 0.10 \times 0.10 \mathrm{~mm}^{3}$ \\
\hline$\theta$ range for data collection & 2.424 to $27.182^{\circ}$ \\
\hline \multirow[t]{3}{*}{ Index ranges } & $-12 \leq h \leq 12$ \\
\hline & $-15 \leq k \leq 15$ \\
\hline & $-16 \leq I \leq 16$ \\
\hline Reflections collected & 49759 \\
\hline \multirow[t]{2}{*}{ Independent reflections } & 11713 \\
\hline & {$[R($ int $)=0.0589]$} \\
\hline Absorption correction & Multi-scan \\
\hline Min. and max. transmission & 0.5867 and 0.7455 \\
\hline Data / restr. / param. & $11713 / 180 / 812$ \\
\hline Goodness-of-fit on $\mathrm{F}^{2}$ & 1.059 \\
\hline Flack parameter & $0.400(7)$ \\
\hline \multirow[t]{2}{*}{ Final $R$ indices $[I>2 \sigma(I)]$} & $\mathrm{R} 1=0.0279$ \\
\hline & $w R 2=0.0501$ \\
\hline Largest diff. peak and hole & 1.607 and -0.725 e $\AA^{-3}$ \\
\hline
\end{tabular}




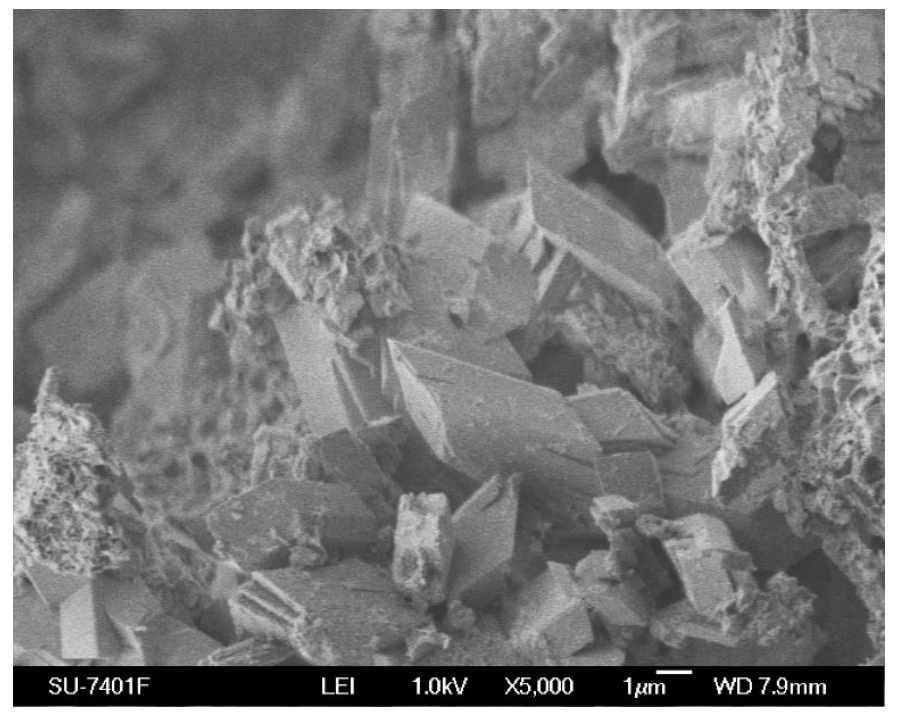

Figure S32. SEM micrograph of $\mathrm{Bi}_{6} \mathrm{O}_{4}\left(\mathrm{H}_{2} \text { TPTC }\right)_{5}(5)$, showing stubby microscale crystals. 


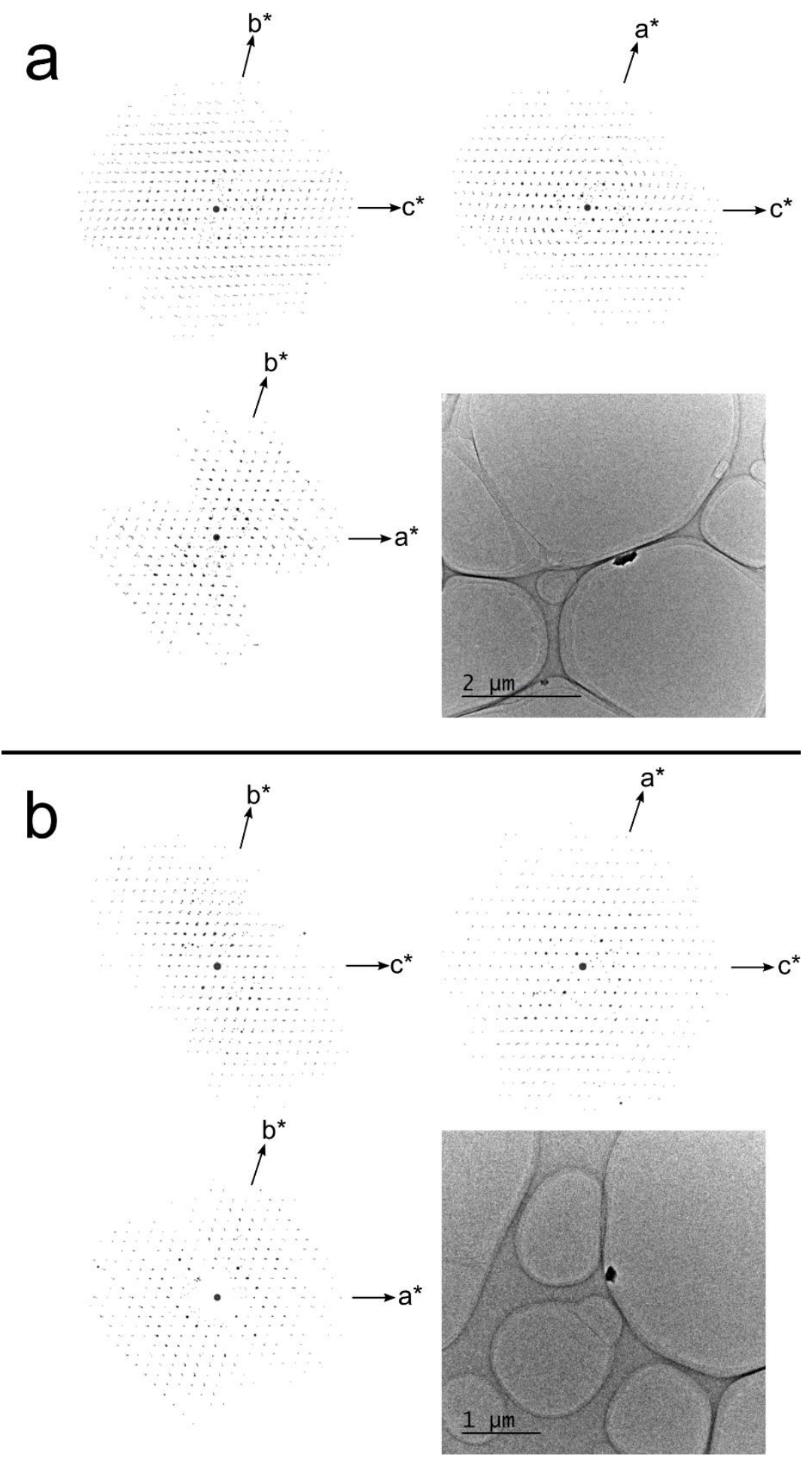

Figure S33. Reciprocal space projection along $a^{*}, b^{*}$ and $c^{*}$, as well the crystals of $\mathrm{Bi}_{6} \mathrm{O}_{4}\left(\mathrm{H}_{2} \text { TPTC }\right)_{5}(5)$ used for data collection, for the data sets $\mathbf{a}$ and $\mathbf{b}$. 
Table S10: Crystallographic table for merged electron diffraction data of $\mathrm{Bi}_{6} \mathrm{O}_{4}\left(\mathrm{H}_{2} T P T C\right)_{5}(5)$.

\begin{tabular}{|c|c|}
\hline Identification Code & $\mathrm{Bi}_{6} \mathrm{O}_{4}\left(\mathrm{H}_{2} \mathrm{TPTC}\right)_{5}(\mathbf{5})$ \\
\hline Wavelength & $0.0251 \AA$ \\
\hline Crystal system & Triclinic \\
\hline Space group & $P \overline{1}($ No. 2$)$ \\
\hline \multirow[t]{6}{*}{ Unit cell dimensions } & $a=11.90 \AA$ \\
\hline & $b=14.49 \AA$ \\
\hline & $c=16.10 \AA$ \\
\hline & $\alpha=102.50^{\circ}$ \\
\hline & $\beta=106.82^{\circ}$ \\
\hline & $\gamma=105.62^{\circ}$ \\
\hline Volume & $2425 \AA^{3}$ \\
\hline Z & 2 \\
\hline \multirow[t]{3}{*}{ Index ranges } & $-11 \leq h \leq 11$ \\
\hline & $-14 \leq k \leq 14$ \\
\hline & $-16 \leq I \leq 16$ \\
\hline Reflections collected & 10729 \\
\hline \multirow[t]{2}{*}{ Independent reflections } & 3883 \\
\hline & {$[\mathrm{R}(\mathrm{int})=0.2126]$} \\
\hline Completeness (to $1.0 \AA$ Å resolution) & $71.9 \%$ \\
\hline $\mathrm{R}_{1}(\mathrm{ED}$ model) $[\mathrm{I}>2 \sigma(\mathrm{I})]$ & 0.1826 \\
\hline
\end{tabular}

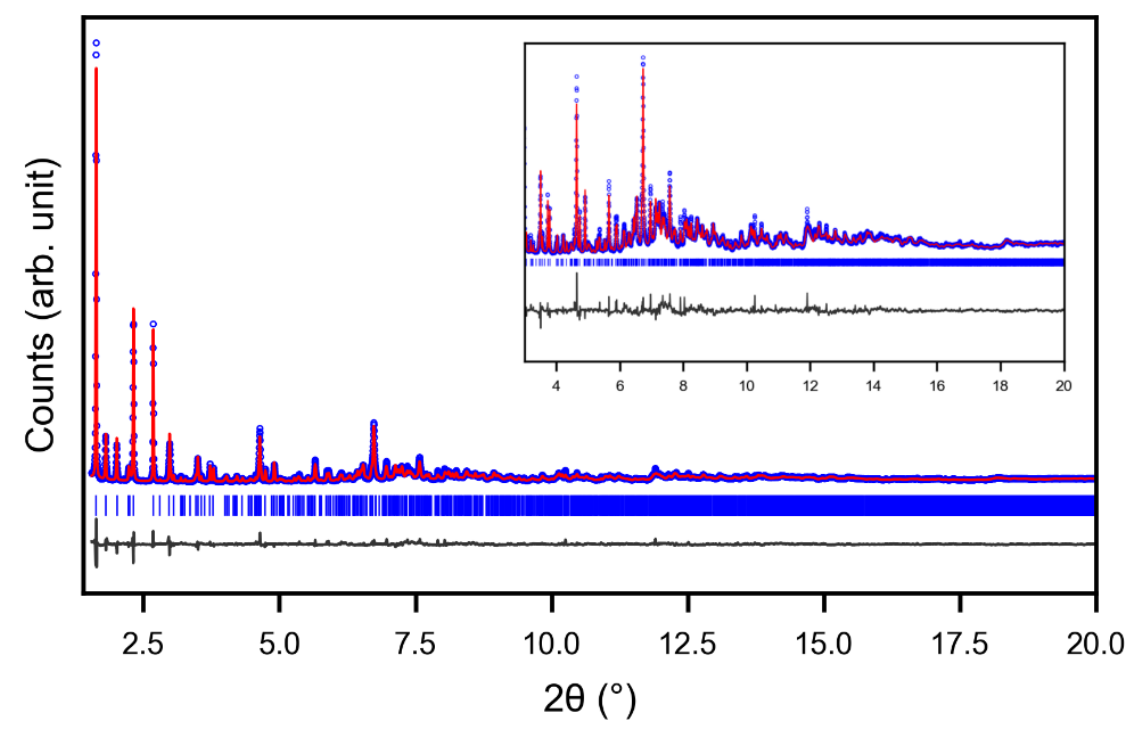

Figure S34. Plot for the structure refinement of $\mathrm{Bi}_{6} \mathrm{O}_{4}\left(\mathrm{H}_{2} \text { TPTC }\right)_{5}(5)$. High resolution XRPD data were collected at $11 \mathrm{BM}$ at the APS, Argonne National Laboratory, $\lambda=0.412735 \AA$. 
Table S11. Crystallographic details from X-ray powder diffraction data and structure refinement details for $\mathrm{Bi}_{6} \mathrm{O}_{4}\left(\mathrm{H}_{2} \mathrm{TPTC}\right)_{5}(5)$.

\begin{tabular}{ll}
\hline Identification code & $\mathrm{Bi}_{6} \mathrm{O}_{4}\left(\mathrm{H}_{2} \mathrm{TPTC}\right)_{5}(\mathbf{5})$ \\
Crystal system & Triclinic \\
Space group & $P \overline{1}(\mathrm{No} .2)$ \\
Unit cell dimensions & $a=11.874(3) \AA$ \\
& $b=14.349(4) \AA$ \\
& $c=16.022(4) \AA$ \\
& $\alpha=102.318(7)^{\circ}$ \\
& $\beta=106.892(7)^{\circ}$ \\
& $\gamma=106.178(5)^{\circ}$ \\
Volume $\left(\AA^{3}\right)$ & $2376(1) \AA^{3}$ \\
Wavelength & $0.412735 \AA$ \\
Refinement method & Profile method \\
Refinement statistics & $R_{\mathrm{wp}}=10.00 \%$ \\
& GOF $=3.02$ \\
\hline
\end{tabular}


Table S12. Summary of crystallographic details and CCDC numbers of all presented structures in this work.

\begin{tabular}{|c|c|c|c|c|c|c|c|}
\hline $\begin{array}{l}\text { Formula } \\
\text { CCDC } \\
\text { number }\end{array}$ & $\begin{array}{c}\mathbf{B i}_{2} \mathbf{O}_{2} \text { (HBPT) } \\
1926729\end{array}$ & $\begin{array}{c}\mathrm{Bi}(\mathrm{OH})\left(\mathrm{H}_{2} \mathrm{BPT}\right)_{2} \\
\left(\mathrm{H}_{2} \mathrm{O}\right)_{2}{ }_{2} \mathrm{H}_{2} \mathrm{O} \\
1926730\end{array}$ & $\begin{array}{c}\mathrm{Bi}_{2}(\mathrm{HBPT})_{3}\left(\mathrm{H}_{2} \mathrm{O}\right)_{3} \\
\cdot \mathrm{H}_{3} \mathrm{BPT} \\
1926731\end{array}$ & $\begin{array}{c}\mathrm{Bi}_{6} \mathrm{O}_{4}\left(\mathrm{H}_{2} \mathrm{TPTC}\right)_{5} \\
1926732\end{array}$ & $\begin{array}{l}\mathrm{Bi}(\mathrm{BPT}) \\
\cdot 2 \mathrm{MeOH} \\
1926733\end{array}$ & $\begin{array}{l}\mathrm{Bi}(\mathrm{BPT}) \\
\cdot 3 \mathrm{MeOH} \\
1926734\end{array}$ & $\begin{array}{c}\mathrm{Bi}(\mathrm{BPT}) \\
\text { •DEF } \\
1926735\end{array}$ \\
\hline $\begin{array}{c}\text { Sample } \\
\text { name } \\
\text { Sample } \\
\text { number }\end{array}$ & 2 & 3 & 4 & 5 & $\begin{array}{l}\text { SU-100 as- } \\
\text { synthesized } \\
\mathbf{1}\end{array}$ & $\begin{array}{c}\mathrm{MeOH} @ \mathrm{SU} \\
-100 \\
\mathrm{MeOH} @ 1\end{array}$ & $\begin{array}{c}\text { DEF@SU- } \\
100 \\
\text { DEF@1 }\end{array}$ \\
\hline $\begin{array}{c}\text { Space group } \\
a / \AA \\
b / \AA\end{array}$ & $\begin{array}{c}P 2_{1} / c \\
3.9144(6) \\
15.015(2)\end{array}$ & $\begin{array}{c}P-1 \\
7.3959(3) \\
11.9364(4)\end{array}$ & $\begin{array}{c}P 1 \\
9.9074(4) \\
11.7713(6)\end{array}$ & $\begin{array}{c}P-1 \\
11.874(3) \\
14.349(4)\end{array}$ & $\begin{array}{c}12 / a \\
17.854(3) \\
9.613(2)\end{array}$ & $\begin{array}{c}12 / a \\
18.0213(6) \\
10.0372(4)\end{array}$ & $\begin{array}{c}12 / a \\
18.018(1) \\
10.8566(8)\end{array}$ \\
\hline $\begin{array}{c}\text { c / } \AA \\
\text { alpha } / \circ \\
\text { beta / } \\
\text { gamma }\end{array}$ & $\begin{array}{c}25.767(4) \\
90 \\
91.645(8) \\
90\end{array}$ & $\begin{array}{c}16.2328(5) \\
99.343(2) \\
92.285(2) \\
97.253(2)\end{array}$ & $\begin{array}{c}12.9136(7) \\
64.992(2) \\
76.477(2) \\
87.906(2)\end{array}$ & $\begin{array}{c}16.022(4) \\
102.318(7) \\
106.892(7) \\
106.178(5)\end{array}$ & $\begin{array}{c}21.047(4) \\
90 \\
96.771(2) \\
90\end{array}$ & $\begin{array}{c}21.2624(8) \\
90 \\
99.206(1) \\
90\end{array}$ & $\begin{array}{c}20.478(1) \\
90 \\
99.1116(5) \\
90\end{array}$ \\
\hline
\end{tabular}


(1) Rohlíček, J.; Hušák, M. MCE2005 - A New Version of a Program for Fast Interactive Visualization of Electron and Similar Density Maps Optimized for Small Molecules. J. Appl. Crystallogr. 2007, 40 (3), 600-601. 